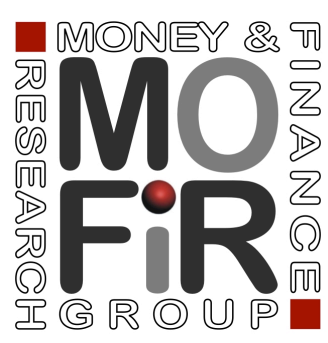

\title{
CREDIT CONSTRAINTS AND \\ FIRM PRODUCTIVITY: EVIDENCE FROM ITALY
}

Francesco Manaresi Nicola Pierri

Working paper no. 137

January 2017 


\title{
Credit Constraints and Firm Productivity: Evidence from Italy
}

\author{
Francesco Manaresi* Nicola Pierri ${ }^{\S}$ \\ First Version: September 2015 \\ This Version: January 2017
}

\begin{abstract}
This paper studies the impact of credit constraints on manufacturers' production. We exploit a matched firm-bank panel data covering all Italian companies over the period 1998-2012 to derive a measure of supply-side shock to firm specific credit constraints, and study how it affects input accumulation and value added productivity. We show that an expansion in the credit supply faced by a firm increases both input accumulation (size effect) and its ability to generate value added for a given level of inputs (productivity effect). Results are robust to various productivity estimation techniques, and to an alternative measure of credit supply shock that uses the 2007-2008 interbank market freeze to control for assortative matching between firms and banks. We discuss different potential channels for the estimated effect and explore their empirical implications.
\end{abstract}

\section{Introduction}

To grow and thrive firms need reliable access to external funding. A growing literature studies how credit market frictions affect the allocation of resources among firms with heterogeneous productivity. These frictions, such as credit constraints, may prevent the market

\footnotetext{
*Bank of Italy, Structural Economic Department.

$\S$ Stanford University.

We thank Nick Bloom, Tim Bresnahan, Matteo Bugamelli, Francesca Carta, Matt Gentzkow, Andrea Linarello, Francesca Lotti, Davide Malacrino, Luigi Pistaferri, Joshua Rauh, Pietro Tebaldi and all partecipants to Stanford IO workshop, Stanford applied economics seminar and Second Bay Area Labor and Public conference for their insightful comments; all errors and mistakes remain our sole responsibility. Corresponding author: Francesco Manaresi, francesco.manaresi@bancaditalia.it.
} 
to equate the marginal product of capital among all firms (Hsieh and Klenow 2009). The inefficient allocation of capital is found to play a significant role in explaining productivity differentials across countries (e.g. Restuccia and Rogerson 2008, Bartelsman et al. 2013). Financial frictions may hamper input allocation mostly by deterring entry and technology adoption (Midrigan and Xu 2014). while among incumbent firms and for given technology their role is mitigated by self-financing (Moll 2014). So far, most of this literature has assumed firm's productivity not to be directly affected by credit frictions. ${ }^{1}$ Yet, better access to external funding may also improve firm's efficiency of production. Indeed, credit constraints may deter technological upgrade, induce factor hoarding, and limit export orientation of firms (Gine and Yang 2009, Meza and Quintin 2007, Paravisini et al. 2014), and here are vast evidence of the impact of these factors on productivity growth ${ }^{2}$.

In this paper we empirically assess whether there is a direct effect of idiosyncratic, time-varying shocks to credit constraints on firm productivity growth. To identify firm-level measures of credit shocks, we consider two different methods. First, we exploit information on credit granted by all banks to all Italian incorporated firms over the period 1998-2012 and, following Amiti and Weinstein (forthcoming), we decompose the growth rate of credit of each bank-firm pair in firm-year and bank-year fixed effects. We then aggregate the bank-year fixed effects at the firm level, using previousyear credit shares as weights, to obtain a proxy of firm-specific credit supply shifters that may relax or tight credit constraints. Second, we focus on the Great Recession (period 2007-2010) and use the identification strategy of Cingano et al. (2016): we exploit banks' pre-crisis differential exposure to the interbank market collapse as a credit supply shock, which is averaged at the firm using pre-crisis credit shares as weights.

\footnotetext{
${ }^{1}$ The work by Caggese (2016), contemporaneous to our research, is a notable exception.

${ }^{2}$ See, for instance, Acemoglu et al. 2006 and De Loecker 2011
} 
We match these idiosyncratic shocks with balance-sheet information for a large sample of around 16K Italian manufacturing firms observed over the period 1998-2012. Consistently with previous literature (e.g. Greenstone et al. 2015, Chodorow-Reich 2014), we find that credit supply affects the size of firms: input accumulation (notably, investments) increase when credit constraints get slacker.

We document that the impact on output is significantly larger than the one on input accumulation, suggesting that it may go beyond the size of activity. We investigate more in depth this finding by estimating value-added total factor productivity (Ackelberg et al. 2015; Wooldridge 2009) using a wide array of functional forms for firm's production, and employing different proxy variables. We also consider a simpler approach by imposing Cobb-Douglas production function and constant return to scale and then either estimating the elasticity to labor using cost share or assuming its value equal to two thirds. Using any of these measures of TFP, we identify a positive productivity effect of expansionary credit shocks. Thus, relaxing of credit constraints do not only allow firms to expand its input endowment, but also increase the ability to generate value added for a given amount of inputs. The effect is found to be particularly relevant for smaller firms (as defined by firm's capital), and it is present both before and during the financial crisis. Our baseline empirical model controls for firm- and year-specific unobserved heterogeneity, as well as lagged measures of firm size (as measured by capital and value added), liquidity, and cashflow, and results are found to be remarkably robust to model specification. ${ }^{3}$ The effect on TFP growth is found to persist for at least 2 years and does not revert overtime, resulting in a permanent differential in productivity levels among firms.

We cannot estimate production function including the constraints

\footnotetext{
${ }^{3}$ Similar (but smaller) results are found when considering net revenues (rather than value added) as relevant measure of output and when including non-manufacturing firms in the sample. These additional results are available upon request.
} 
directly, since we do not observe their exact value but only some plausibly exogenous shifter. Therefore, to address the issues raised by DeLocker (2013), which apply to our setting, we show that, at least in the value added case, any reasonable values for the parameters implies a positive productivity effect of credit availability. Furthermore, the elasticities estimated by ignoring the role of credit constraints are still consistent under the null, therefore all hypothesis-testing exercises are statistically valid. Because of the same measurement problem, we can only infer the magnitude of the productivity effect in an approximate and heuristic way.

We provide preliminary empirical evidence on some potential channels. We find that credit shocks affect the probability that the firm engages in R\&D (Aghion et al. 2012) and exports (Paravisini et al. 2014, De Loecker 2011), while we fail to identify a significant impact on ICT adoption. However, a more in-depth investigation of the mechanisms is left to future research.

The productivity effect of credit shocks has implications for several recent topics in economic research. First, it may help explain part of the large differences in firm productivity, measured within narrowly defined sectors, that have been consistently found by economic scholars (Syverson 2011). While several potential causes have been identified in the literature (such as management practices, R\&D activities, IT adoption, incentive payments, or learning-bydoing),$^{4}$ the roots of this heterogeneity may be partly traced back to unequal access to external funds.

Second, our work is related to the growing literature which exploit borrowers-lenders matches information to study real effects of financial shocks, such as Chodorow-Reich (2014), Jiménez et al (2012), Paravisini et al (2014), Iyer et al (2014), Schnabl (2012). Some recent developments have relied on the same Italian data we employ

\footnotetext{
${ }^{4}$ See, for instance, Doraszelski and Jaumandreu (2013), Bloom et al (2012), Lazear (2000), and Benkard (2000).
} 
in this work: Cingano et al (2016), Bonaccorsi di Patti and Sette (2015), Buono and Formai (2016), Bottero, Lenzu and Mezzanotti (2015). All these papers have focused on identifying the effect on input accumulation (what we call "size effect"). We contribute to this literature by considering the impact on the whole production function. This allows us to pinpoint the additional productivity effect of financial shocks to the real economy.

Another strand of the literature studied real effects of financial shocks using a macroeconomic perspective (e.g, Jorda et al (2012) and Reinhart and Rogoff (2009)). In particular, our finding is an important complement to the works relating the consequences of allocation of resources to aggregate productivity, such as Hsieh and Klenow (2009), Midrigan and Xu (2014), Moll (2014), and Gopinath et al. (2015), who focus on southern European countries.

Since the credit constraints are a specific form of financing constraints, this paper is closely related to the corporate finance literature which analyze the effects of financial frictions on investment, such as Fazzari et al (1988) and Rauh (2006). Finally, our work is related to the theoretical and empirical treatment of innovation dependence on financing frictions: see Caggese (2016) and GarciaMacia (2015) for recent examples.

Our focus on Italy is not only driven by the extremely rich data available for this country, which is crucial for our empirical strategy. Indeed, studying firms' productivity in Italy is of paramount importance since the country has been experiencing a long-lasting productivity slump (Accetturo et al. 2013). Credit constraints may be particularly relevant in explaining this trend, as Italian firms are extremely reliant on banks' external funds. ${ }^{5}$

\footnotetext{
${ }^{5}$ Italian firms have higher leverage than their US (or other European countries) counterparts and also a larger share of bank debt over total financial liabilities. Elaboration of the authors on the survey of lenders carried by ECB show that Italian firms have on average $43.8 \%$ leverage versus $26.6 \%$ for US counterpart, and that more than $60 \%$ of their debt is coming from banks.
} 
The remainder of the paper is structured as follows. Section 2 describes the data used in the analysis, while Section 3 introduces the general framework guiding empirical exercise. Section 4 describes the general measure of credit supply shifters. Section 5 reports and comments the results on the productivity effect of credit constraints. Section 6 presents the complementary identification strategy exploiting the interbank market collapse as a credit supply shifter. Section 7 reports several robustness exercises. Section 8 investigates persistence, heterogeneity and possible mechanisms behind the effect we document. Section 9 concludes.

\section{Data}

One key contribution of this paper is to bring together two literatures: the one that studies the economic activity of the firm within the theoretical framework of a production function, and the empirical finance literature that studies the effects of credit supply shocks. Production function estimate rely on detailed firm balance-sheet information, while sound identifications of credit supply shocks are currently based on firm-bank matched data. We are able to link these two types of data together to perform our empirical exercise.

\subsection{Firm balance-sheets: the CADS dataset}

The Company Accounts Data System (CADS) is a proprietary database administered by CERVEDGroup Ltd. for credit risk evaluation. It collects detailed balance-sheet and income statement information on a large sample of non-financial incorporated firms since 1982. It is used by banks for credit decisions and, hence, the data are carefully controlled.

We focus on firms active in manufacturing sectors. ${ }^{6}$ Firms in CADS account for a large share of total value added of Italian in-

\footnotetext{
${ }^{6}$ Results available from the authors upon request show that the main results hold when using a larger sample including non-manufacturing sectors.
} 
corporated manufacturing firms. The sample, however, is not randomly drawn, since a firm is observed only if it has ever borrowed from at least one bank.

From CADS we select balance-sheet data from 1998 to $2012^{7}$ to obtain the main variables we use in our production function estimation. Firm's level of overall capital in each year is estimated from information on book-value of capital, investments, divestments, and depreciation using the perpetual-inventory method ${ }^{8}$. Operative value added, expenditure in services and expenditure in row materials (and intermediates) are taken from profit-and-loss statements and deflated using sector-level deflators from national accounts. Labor is measured by the wage bill, deflated using CPI. ${ }^{9}$ We also include additional firm characteristics, such as cash-flow and liquidity, that will be used as firm-level controls.

The table below reports descriptive statistics of these variables. Yearly value added for the mean firm is around $€ 6 \mathrm{mln}$, whlie its distribution is right-skewed: the median firm's value added being around $1 / 4$ of the mean. A similar positive difference between mean and median values can be observed also for production inputs (columns 2 to 5). Mean and median of the main variables are extremely similar once log transformation is applied, as shown by table 10 in the appendix.

\footnotetext{
${ }^{7}$ We also use balance-sheet information from 1996 and 1997 to compute lags and growth rates of the variables of interests.

${ }^{8}$ Capital series are built by Lenzu and Manaresi (2016), using sector-specific investment deflators and depreciation rates.

${ }^{9}$ In a robustness test we use headcount, which is available for only part of the sample, as measure of labor input and results do not vary dramatically.
} 


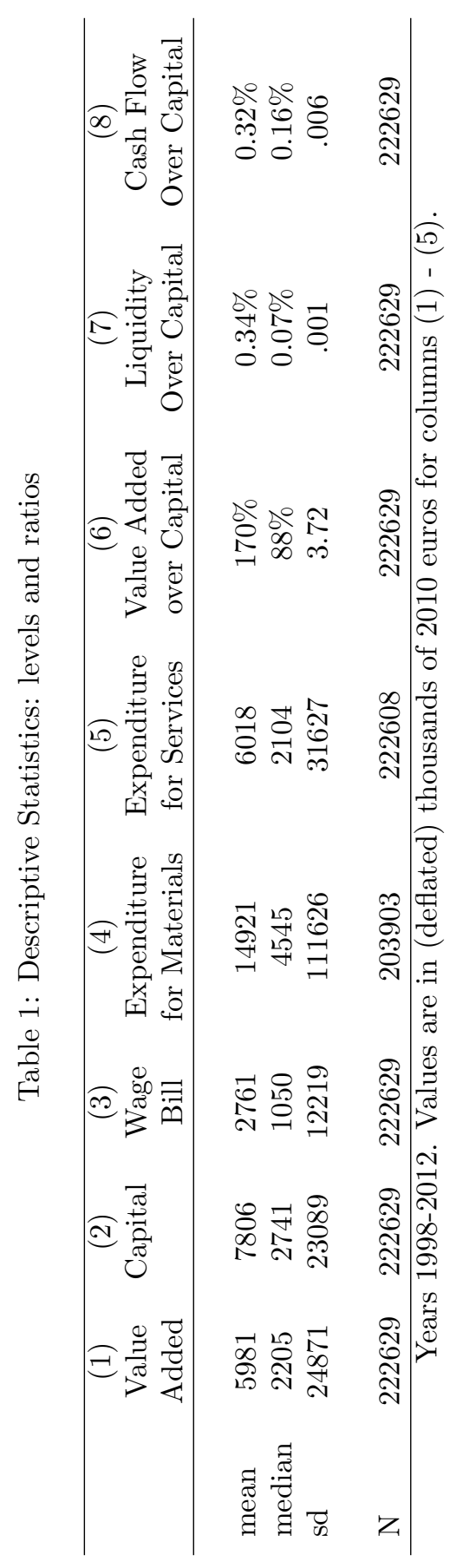




\subsection{Firm-bank matched data: the Italian Credit Register}

The Italian Credit Register (CR), owned by the Bank of Italy, collects from all intermediaries operating in Italy (banks, other financial intermediaries providing credit, special purpose vehicles) individual data on borrowers with exposures above 75,000 euros towards a single intermediary. Exposures include both debt and guarantees. A borrower with debt of, say, 20,000 euros towards a bank appears in the CR if she also provides guarantees worth at least 55,000 euros to another individual borrowing from the same bank. ${ }^{10}$ The CR contains data on the outstanding bank debt of each borrower, distinguished into loans backed by account receivables, term loans, and revolving credit lines. The CR also contains information about the granting institution and the unique tax identification number of the borrower. Banks routinely use the $\mathrm{CR}$ as a tool to monitor borrowers, which ensures a high quality of the data. We select credit relationships between all banks and all Italian incorporated firms in each year from 1998 to 2012 (we use 1997 data to compute growth rates).

We consider total quantity of outstanding credit granted at the end of each year. We do not differentiate between different kind of credit (for instance credit line versus loans), because the choice of which type of credit to increase/decrease is ultimately the result of strategic bargaining between banks and firms. We also focus on credit granted rather than on credit used, as the latter is more likely affected by credit demand.

Table 12 in the appendix, provides descriptive statistics of the CR dataset. On average, we have information for 468,984 firms and 1,008 banks per year. Each firm has a relationship with 2.8 banks (around $45 \%$ of firms have a credit relationship with just one bank), while the average number of relationships each bank has is

\footnotetext{
${ }^{10}$ The 75,000 euros threshold has been lowered to 30,000 euros since January 2009; in a robustness exercise we show our analysis is not affected by the change in threshold.
} 
1,321. Finally, the average credit granted in each relationship is $€ 529$ thousands. $^{11}$

\section{General Framework}

Consider a firm $i$ operating in sector $s$ at time $t$. The firm combines capital $K_{i, t}$ and labor $L_{i, t}$ to generate value added $V A_{i, t}$ (i.e., output value net of variable $\left.\operatorname{costs}^{12}\right)$ according to the function:

$$
V A_{i, t}=\Omega_{i, t} F^{s}\left(K_{i, t}, L_{i, t}\right)
$$

where $F^{s}(\cdot)$ is a sector specific production function, and $\Omega_{i, t}$ is firm's idiosyncratic Hicks-neutral productivity. Let all the firms in the sector be facing same prices, so that we can express inputs in terms of their expenditures.

Firm's choices are subject to two dynamic constraints:

$$
K_{i, t}=K_{i, t-1}\left(1-\delta_{s}\right)+I_{i, t}
$$

and

$$
K_{i, t} \leq K_{i, t-1} \cdot \Lambda_{i, t}
$$

The first equation is the law of motion of capital, for which we allow depreciation $\delta_{s}$ to be sector-specific, and where $I_{i, t}$ are expenditures in investments goods, such as machinery or buildings.

The second equation is a simple representation of credit constraints, where $\Lambda_{i, t}$ measures the firm-specific strength of such friction, and $\Lambda_{i, t} \rightarrow \infty$ corresponds to the case of perfect access to capital markets. The constraint may also be interpreted as a financiallyoriginated capital adjustment cost. Notice that equation (3) is isomorphic to other representations linking capital acquisition to finan-

\footnotetext{
${ }^{11}$ We focus on banks, rather than banking groups, as relationship lending is usually based at the bank-level. Results using data aggregated at the banking group level, available upon request by the author, are nonetheless qualitatively and quantitatively very similar.

${ }^{12}$ Gross of labor cost.
} 
cial variables, such as the one used by Midrigan and Xu (2014), and Moll (2014). ${ }^{13}$

Heterogeneity in $\Lambda_{i, t}$, both in the cross-section of firms and over time, may reflect several factors, such as financial markets' and firms' characteristics. For instance, a large literature documents that firms have lower credit constraints in more competitive financial markets (e.g., Kerr and Nanda (2009); Bertrand, Schoar, and Thesmar (2007)). Furthermore, more profitable firms might have slacker capital constraints (i.e., higher $\Lambda$ ) because lenders are able to identify them. Finally, firms can endogenously reduce their constraint by accumulating liquid assets. ${ }^{14}$

We study how an exogenous shock to $\Lambda_{i, t}$ affects firm's value added $V A_{i, t}$. From (1), with an abuse of notation ${ }^{15}$ and omitting subscripts for simplicity, we get:

$$
\frac{\partial V A}{\partial \Lambda}=\Omega\left(\frac{\partial F}{\partial K} \cdot \frac{\partial K}{\partial \Lambda}+\frac{\partial F}{\partial L} \cdot \frac{\partial L}{\partial \Lambda}\right)+\frac{\partial \Omega}{\partial \Lambda} \cdot F
$$

where $K$ and $L$ are the constrained optimal quantities. The first polynomial, in parentheses, is the size effect: the impact of credit constraints on input accumulation. The last derivative $\partial \Omega / \partial \Lambda$ represents the productivity effect: an impact on the ability to produce value added, conditional on the level of inputs. In Section ??, we provide evidence of the effect of credit shocks to input accumulation $(\partial K / \partial \Lambda$ and $\partial L / \partial \Lambda)$. As previously discussed, several papers have estimated the impact of a shock to credit constraints on inputs: for instance, Gan (2009), Amiti and Weinstein (2013), and Cingano et al. (2016) focus on $\frac{\partial K}{\partial \Lambda}$, finding a positive effect; while Chodorow-

\footnotetext{
${ }^{13}$ For instance, Moll (2014) writes $K_{i, t} \leq \Lambda A_{i, t}$ where $A$ is the net asset position of the entrepreneur. Since we are allowing the constraint to be firm-specific and time varying, we can define $a_{i, t}=\frac{A_{i, t}}{K_{i, t}}$ and write $K_{i, t} \leq K_{i, t-1} \cdot \Lambda_{i, t}$ with $\Lambda_{i, t}=\Lambda \cdot a_{i, t-1}$. Notice that we consider the net worth of the company rather than the one of the entrepreneur.

${ }^{14}$ Although we do not explicitly model companies' possibility to "save out constraints" (as in Moll 2014), we control for liquidity and cash flow in our empirical specifications.

${ }^{15}$ We use derivative sign to indicate both changes in equilibrium quantities due to external shocks to the constraints and elasticities of the production function with respect to inputs.
} 
Reich (2014), Bentolilla et al. (2014), and Greenstone et al. (2015) identify $\frac{\partial L}{\partial \Lambda}>0$. Under the null-hypothesis, these impacts are the only channels through which value added can be affected

Our central research question is, thus, testing the null-hypothesis:

$$
H_{0}: \quad \frac{\partial \Omega}{\partial \Lambda}=0
$$

Under $H_{1}$, aside from the size effect, credit constraints have a significant productivity effect.

To empirically test this hypothesis, we start from equations (1) and (3); switching to logarithms we get:

$$
\begin{gathered}
\omega_{i, t}=v a_{i, t}-f^{s}\left(k_{i, t}, l_{i, t}\right) \\
\lambda_{i, t} \geq \Delta k_{i, t}
\end{gathered}
$$

We posit a linear relationship between the logarithmic transformation of idiosyncratic productivity and constraint:

$$
\omega_{i, t}=\tilde{\psi}_{t}+\tilde{\psi}_{i}+\alpha \lambda_{i, t}+\tilde{\eta}_{i, t}
$$

where $\tilde{\psi}$ 's represent fixed effects, while $\tilde{\eta}_{i, t}$ is the part of idiosyncratic productivity not affected by financial friction. We can now perform a two-sided test:

$$
H_{0}: \alpha=0 \quad H_{1}: \alpha \neq 0
$$

While theoretically very simple, there are several reasons for which the empirical implementation of this test represents a though challenge. First, neither productivity nor credit constraints can be directly observed by the econometrician. Productivity estimation entails a plethora of identification issues, as highlighted by the large literature devoted to this task (e.g., Ackerberg er al. 2007). Proxies of $\lambda_{i, t}$ have been historically based on balance-sheets variables, such as firm's cash-holdings. Yet, the validity of such proxies has been 
effectively questioned (Kaplan and Zingales 1997).

Even if the researcher could observe both $\lambda_{i, t}$ and $\omega_{i, t}$, we would need to assume some form of independence between the error in equation (8) and the credit constraint to test $H_{0}$ using a simple correlation. This might be an extremely undesirable assumption. For instance, better firms might be considered safer borrowers and, therefore, face slacker financial constraints; also, aggregate or sectorspecific shocks may affect both productivity and their access to capital markets. Some of these contextual confounding factors may be controlled for using fixed effects or observable covariates, yet potential biases in estimating $\alpha$ may hardly be ruled out.

In the next sections, we detail how we tackle each of these issues. In particular, we apply several state-of-the-art methodologies to estimate sector-specific production functions and obtain firm-specific productivity levels. Then, we describe our proxy for shifts in capital constraints $\left(\lambda_{i, t}\right)$, and we discuss the assumptions under which it can be considered exogenous with respect to productivity. Lastly, we exploit some specific events affecting banks ability to finance their borrowers to provide an alternative testing strategy.

\section{Credit Supply Shifter}

In order to derive a shifter of credit constraints which is both firmspecific and independent with respect to shocks to its demand and productivity growth, we focus on bank credit. We leverage on the information provided by Italian Credit Register which collects information on the total amount of lending provided by all Italians bank to firms (see Section 2). Let $C_{i, b, t}$ be total outstanding credit granted by bank $b$ to firm $i$ at time $t$, and $\Delta c_{i, b, t}$ its growth rate (as proxied by the delta-log difference). Inasmuch each firm borrows from at least 2 banks, we can follow Amiti and Weinstein (forthcoming) and decompose this growth rate into firm-specific and bank-specific 
shocks:

$$
\Delta c_{i, b, t}=\phi_{b, t}+\chi_{i, t}+\xi_{i, b, t}
$$

We interpret $\phi_{b, t}$ as approximation for bank-specific changes in credit supply between year $t$ and $t-1$. We aggregate these bankspecific shocks at the firm-level to obtain a firm-specific shifter of financial constraints:

$$
s_{i, t}=\sum_{b=1}^{B} w_{i, b, t-1} \phi_{b, t}
$$

where $w_{i, b, t-1}=C_{i, b, t-1} / \sum_{b} C_{i, b, t-1}$ is previous-period ${ }^{16}$ share of total credit to firm $i$ coming from bank $b .{ }^{17}$ In our sample, this shifter of financial constraints has mean equal to 0.0019, median 0.0091, and standard deviation 0.0379 .

Several remarks can be made here. First, notice that, while $\phi_{b, t}$ can be estimated solely from firms with multiple lending relationships, $s_{i, t}$ can be attributed also to firms who borrow from just one bank. Second, for $s_{i, t}$ to be a relevant proxy of changes in financial constraints, firms must not to be able to fully substitute the negative supply shock from one bank with credit from other banks. There is large evidence that this substitutability is far from perfect (Khwaja and Mian (2008), Chodorow-Reich (2014), Jiménez et al. (2012)). Usually this imperfect substitutability is explained by asymmetric information, that can be mitigated by relationship lending (see Sette and Gobbi (2015) for Italian evidence). Indeed, banks acquire privileged information on its clients and borrowers, decreasing the amount of asymmetry. Moreover, the opportunity of future credit fosters incentives to repay, mitigating concerns related to limited commitment.

\footnotetext{
${ }^{16}$ We adopt a simple and transparent definition of firm-bank connection: firm $i$ is connected to bank $b$ iff $C_{i, b, t}>0$.

${ }^{17}$ Alternatively, one may compute the unweighted average of bank-specific shocks. Baseline results using this definition, available upon request, do not differ both qualitatively and quantitatively.
} 
Second, identification of $\phi_{b, t}$ is based on an addictive assumption on the structure of demand and supply. This assumption, while largely made by the empirical literature on financial shocks, does not come without loss of generality. For it to be valid, it must be that banks share the same information set about all borrowers they are connected to, and evaluate similarly these information. ${ }^{18}$ Third, firm-bank matched preferences must be either constant over time or uncorrelated with credit supply shocks. For instance, let $X_{i t}$ be a firm characteristics, such as book value of asset and $X_{b t}$ be a bank characteristics, such as leverage in previous period. Then, if banks with higher leverage contract their credit during period $t$ but do so less for firms with high book value, then we would need to write:

$$
\Delta c_{i, b, t}=\beta_{1} X_{i t}+\beta_{2} X_{b t}+\beta_{3} X_{b t} X_{i t}+\xi_{i, b, t}
$$

and the additive assumption would fail.

\subsection{Testing the Credit-Supply Shifter}

To test whether our measure of credit supply shifter is effective, we perform some simple assessment exercises.

Assume $s_{i, t}$ identifies a shift in credit constraints. Then, we may posit the following relation:

$$
\Delta \lambda_{i, t}=\theta_{0}+\theta_{1} s_{i, t}+\epsilon_{i, t}
$$

with $\theta_{1}>0$. Recalling inequality (7), we write

$$
\begin{aligned}
\Delta k_{i, t} & \leq \lambda_{i, t} \Rightarrow \\
\Delta^{2} k_{i, t} \leq \Delta \lambda_{i, t} & =\theta_{0}+\theta_{1} s_{i, t}+\epsilon_{i, t}
\end{aligned}
$$

In the case of firms for which the constraint is binding both in $t$

\footnotetext{
${ }^{18}$ Most of "hard" information available to a connected bank is conveyed by the Credit Register and firm balance-sheet; i.e., the same data we exploit.
} 
and $t-1$, we have:

$$
\Delta^{2} k_{i, t}=\theta_{0}+\theta_{1} s_{i, t}+\epsilon_{i, t}
$$

where $\Delta^{2} k_{i, t}$ is the change in net investment flows. Because we cannot directly observe the subset of constrained firms in the sample, we are not able to pin down $\theta_{1}$ empirically. Rather, under simple monotonicity assumption, we may estimate the sign of the effect.

Furthermore, if the shifter moves firm specific credit supply, there must be an effect on the amount of credit received. To test this additional hypothesis, we may run

$$
\Delta c_{i, t}=\theta_{0}^{c}+\theta_{1}^{c} s_{i, t}+\epsilon_{i, t}^{c}
$$

where $\Delta c_{i, t}$ is the change in (log) credit granted between year $t-1$ and $t$. Importantly, $c_{i, t}$ includes the total amount of outstanding credit to the firm, not only the credit provided by lenders with pre-existing connection. Thus, the estimate of $\theta_{1}^{c}$ can be informative about the presence of sizable substitution effects (Jimenez et al. 2014)

Empirically, we exploit the panel dimension of our dataset, by including firm and year fixed-effects. ${ }^{19}$ The former controls for firm characteristics that are constant overtime, the latter for business cycle factors. We also include a set of (lagged) controls: a third degree polynomial in capital (to control for size), ratios of VA to capital (as a proxy of firm's profitability), and two measures of internal finance: liquidity to capital and cash-flow to capital ratios. ${ }^{20}$

Results are presented in table (2) below: we estimate a positive and statistically significant (at any confidence level) effect of the shifter on credit growth and acceleration in capital accumulation: this finding confirms the intuition that positive supply shocks captured by the shifter are associated with constraints getting slacker,

\footnotetext{
${ }^{19}$ That is, $\theta_{0}=\theta_{t}+\theta_{i}$ and $\theta_{0}^{c}=\theta_{t}^{c}+\theta_{i}^{c}$.

${ }^{20}$ In estimating (12) and (13), we include also firms having a single lending relationship.
} 
namely $\theta_{1}>0$. An increase in credit supply is translated one to one to actual credit: it might indicates that substitution between banks is not meaningfully affecting the estimate of supply shocks. A one standard deviation increase in the shifter is associated with an increase in $\Delta^{2} k_{i, t}$ of around $0.3 \%$, which is about half of the size of its median and less than $1 \%$ of its standard deviation. The inclusion of controls does not change coefficient on credit and amplifies coefficients on capital accumulation.

Table 2: Credit supply shifter on credit granted and capital accumulation

\begin{tabular}{|c|c|c|c|c|}
\hline VARIABLES & $\begin{array}{c}(1) \\
\Delta c_{i, t}\end{array}$ & $\begin{array}{c}(2) \\
\Delta c_{i, t}\end{array}$ & $\begin{array}{c}(3) \\
\Delta^{2} k_{i, t} \\
\end{array}$ & $\begin{array}{c}(4) \\
\Delta^{2} k_{i, t} \\
\end{array}$ \\
\hline$s_{i, t}$ & $\begin{array}{c}1.045^{* * *} \\
(0.0417)\end{array}$ & $\begin{array}{c}1.038^{* * *} \\
(0.0416)\end{array}$ & $\begin{array}{c}0.0768^{* * *} \\
(0.0334)\end{array}$ & $\begin{array}{c}0.102^{* * *} \\
(0.0317)\end{array}$ \\
\hline$K_{i, t-2}$ & & $\begin{array}{c}-0.546^{* * *} \\
(0.0619)\end{array}$ & & $\begin{array}{c}0.129 * * * \\
(0.0346)\end{array}$ \\
\hline$K_{i, t-2}^{2}$ & & $\begin{array}{c}0.130^{* * *} \\
(0.0309)\end{array}$ & & $\begin{array}{c}-0.0360 * * * \\
(0.0102)\end{array}$ \\
\hline$K_{i, t-2}^{3}$ & & $\begin{array}{c}-0.00773^{* * *} \\
(0.00237)\end{array}$ & & $\begin{array}{c}0.00230 * * * \\
(0.000796)\end{array}$ \\
\hline$\frac{v a_{i, t-2}}{k_{i, t-2}}$ & & $\begin{array}{l}0.00168^{*} \\
(0.000881)\end{array}$ & & $\begin{array}{c}-0.0216^{* * *} \\
(0.00332)\end{array}$ \\
\hline$\frac{\text { liqudity }_{i . t-2}}{k_{i, t-2}}$ & & $\begin{array}{c}-0.0638 \\
(0.210)\end{array}$ & & $\begin{array}{c}-2.627^{* * *} \\
(0.470)\end{array}$ \\
\hline$\frac{\text { cashflow }_{i, t-2}}{k_{i, t-2}}$ & & $\begin{array}{c}1.555^{* * *} \\
(0.536)\end{array}$ & & $\begin{array}{c}-2.509^{* *} \\
(1.206)\end{array}$ \\
\hline $\begin{array}{l}\text { Firm FEs } \\
\text { Year FEs }\end{array}$ & $\begin{array}{l}\mathrm{Y} \\
\mathrm{Y}\end{array}$ & $\begin{array}{l}\mathrm{Y} \\
\mathrm{Y}\end{array}$ & $\begin{array}{l}\mathrm{Y} \\
\mathrm{Y}\end{array}$ & $\begin{array}{l}\mathrm{Y} \\
\mathrm{Y}\end{array}$ \\
\hline $\begin{array}{l}\text { Observations } \\
R^{2}\end{array}$ & $\begin{array}{c}207823 \\
0.193\end{array}$ & $\begin{array}{c}207823 \\
0.195\end{array}$ & $\begin{array}{c}207823 \\
0.168\end{array}$ & $\begin{array}{c}207823 \\
0.192\end{array}$ \\
\hline
\end{tabular}




\section{$5 \quad$ Effect of Shocks to Credit Supply}

\subsection{Value Added and its Input}

We move now to investigate the effect of credit shock to inputs and output. We consider the credit-supply shifter as an exogenous shocks of credit conditions and we use it as a regressor. It is fundamental to notice that we are not instrumenting credit level or growth with the shifter: we are interested in understanding the effect of a specific friction on firms' behavior and outcome, not of the credit itself, which is an equilibrium quantity.

The dependent variable of interest is the log growth rate in value added and its inputs: capital and labor. As before, each observation represents one Italian manufacturing firm (belonging to CADS) for one year between 1998 and 2012 (panel). Estimation are performed using only within-firm variation (firm FEs). We also include year FEs and a set of (lagged) controls: third degree polynomial in capital (measure of size), ratios of VA to capital, liquidity to capital, and cash-flow to capital.

Results, which are presented in table 3 below, shows that the credit shifter has a positive and statistically significant effect on the growth rate of value added and capital, but a much smaller (and not distinguishable from zero) effect on labor expenditure. Firms facing slacker credit constraints increase their investment and produce more value added. We can use the result from table 2 to interpret the magnitude of the effects: the same positive supply-shock that is needed to increase credit granted by $1 \%$ cause an increase in capital of around $0.07 \%$ to $0.09 \%$ and an increase in value added of about $0.16 \%$.

The punchline of table 3 is that the output responds to expansion (or contraction) in credit supply more strongly that inputs. This statistical finding is the cornerstone of our analysis. For in- 
stance, let us consider the columns denoted by odd numbers. The sum of the elasticity of capital and labor to the shifter is about 0.1, less than the elasticity of the value added. If we were to impose a Cobb-Douglas structure on this data, these estimates would imply that even if the production function parameters were both equal to one (which would imply an unreal $200 \%$ return to scale), then the effect of credit shifter on value added could not be explained with its effect on inputs alone.

Table 3: Credit supply shifter on Value Added and its input

\begin{tabular}{|c|c|c|c|c|c|c|}
\hline VARIABLES & $\begin{array}{c}(1) \\
\Delta k_{i, t}\end{array}$ & $\begin{array}{c}(2) \\
\Delta k_{i, t}\end{array}$ & $\begin{array}{c}(3) \\
\Delta l_{i, t}\end{array}$ & $\begin{array}{c}(4) \\
\Delta l_{i, t}\end{array}$ & $\begin{array}{c}(5) \\
\Delta v a_{i, t}\end{array}$ & $\begin{array}{c}(6) \\
\Delta v a_{i, t}\end{array}$ \\
\hline$s_{i, t}$ & $\begin{array}{c}0.0902^{* * *} \\
(0.0196)\end{array}$ & $\begin{array}{c}0.0714^{* * *} \\
(0.0186)\end{array}$ & $\begin{array}{c}0.00812 \\
(0.0157)\end{array}$ & $\begin{array}{r}0.00167 \\
(0.0156)\end{array}$ & $\begin{array}{c}0.164^{* * *} \\
(0.0273)\end{array}$ & $\begin{array}{c}0.157^{* * *} \\
(0.0272)\end{array}$ \\
\hline$K_{i, t-2}$ & & $\begin{array}{c}-1.013^{* * *} \\
(0.0669)\end{array}$ & & $\begin{array}{c}-0.288^{* * *} \\
(0.0224)\end{array}$ & & $\begin{array}{c}-0.288^{* * *} \\
(0.0350)\end{array}$ \\
\hline$K_{i, t-2}^{2}$ & & $\begin{array}{c}0.272^{* * *} \\
(0.0409)\end{array}$ & & $\begin{array}{c}0.0933^{* * *} \\
(0.0112)\end{array}$ & & $\begin{array}{c}0.115^{* * *} \\
(0.0136)\end{array}$ \\
\hline$K_{i, t-2}^{3}$ & & $\begin{array}{c}-0.0177^{* * *} \\
(0.00310)\end{array}$ & & $\begin{array}{c}-0.00618^{* * *} \\
(0.000847)\end{array}$ & & $\begin{array}{c}-0.00766^{* * *} \\
(0.00109)\end{array}$ \\
\hline$\frac{v a_{i . t-2}}{k_{i, t-2}}$ & & $\begin{array}{r}-1.62 \mathrm{e}-07 \\
(3.19 \mathrm{e}-07)\end{array}$ & & $\begin{array}{c}-2.05 \mathrm{e}-06^{* * *} \\
(2.76 \mathrm{e}-07)\end{array}$ & & $\begin{array}{c}-4.74 \mathrm{e}-06 * * * \\
(6.60 \mathrm{e}-07)\end{array}$ \\
\hline$\frac{\text { liqudity }_{i . t-2}}{k_{i, t-2}}$ & & $\begin{array}{c}1.831^{* * *} \\
(0.286)\end{array}$ & & $\begin{array}{c}0.379^{* *} \\
(0.163)\end{array}$ & & $\begin{array}{c}0.923^{* * *} \\
(0.213)\end{array}$ \\
\hline$\frac{\text { cashflow }_{i . t-2}}{k_{i, t-2}}$ & & $\begin{array}{c}8.019^{* * *} \\
(0.532)\end{array}$ & & $\begin{array}{c}0.748^{* * *} \\
(0.187)\end{array}$ & & $\begin{array}{c}-2.795^{* * *} \\
(0.303)\end{array}$ \\
\hline $\begin{array}{l}\text { Firm FEs } \\
\text { Year FEs }\end{array}$ & $\begin{array}{l}\mathrm{Y} \\
\mathrm{Y}\end{array}$ & $\begin{array}{l}\mathrm{Y} \\
\mathrm{Y}\end{array}$ & $\begin{array}{l}\mathrm{Y} \\
\mathrm{Y}\end{array}$ & $\begin{array}{l}\mathrm{Y} \\
\mathrm{Y}\end{array}$ & $\begin{array}{l}\mathrm{Y} \\
\mathrm{Y}\end{array}$ & $\begin{array}{l}\mathrm{Y} \\
\mathrm{Y}\end{array}$ \\
\hline $\begin{array}{l}\text { Observations } \\
R^{2}\end{array}$ & $\begin{array}{c}222629 \\
0.323\end{array}$ & $\begin{array}{c}222629 \\
0.357\end{array}$ & $\begin{array}{c}222629 \\
0.318\end{array}$ & $\begin{array}{c}222629 \\
0.322\end{array}$ & $\begin{array}{c}222629 \\
0.234\end{array}$ & $\begin{array}{c}222629 \\
0.237\end{array}$ \\
\hline
\end{tabular}

This finding is extremely important, because it reassure us that 
effect of the shifter on productivity is totally driven by data and not by the specific procedure used to estimate production function, which are usually very demanding in terms of assumption required to deliver consistent estimates. To be more clear, let us consider again the Cobb-Douglas case:

$$
\begin{gathered}
v a_{i, t}=\beta^{k} k_{i, t}+\beta^{l} l_{i, t}+\omega_{i, t} \Rightarrow \\
\Delta v a_{i, t}=\beta^{k} \Delta k_{i, t}+\beta^{l} \Delta l_{i, t}+\Delta \omega_{i, t}
\end{gathered}
$$

Using again the derivative sign, with an abuse of notation, we write

$$
\begin{aligned}
& \frac{\partial \Delta v a}{\partial \Delta \lambda}=\beta^{k} \cdot \frac{\partial \Delta k}{\partial \Delta \lambda}+\beta^{l} \cdot \frac{\partial \Delta l}{\partial \Delta \lambda}+\frac{\partial \Delta \omega}{\partial \Delta \lambda} \\
& \frac{\partial \Delta \omega}{\partial \Delta \lambda}=\frac{\partial \Delta v a}{\partial \Delta \lambda}-\beta^{k} \cdot \frac{\partial \Delta k}{\partial \Delta \lambda}-\beta^{l} \cdot \frac{\partial \Delta l}{\partial \Delta \lambda}
\end{aligned}
$$

given that, for each variable $X$

$$
\frac{\partial \Delta X}{\partial \Delta \lambda}=\frac{\partial \Delta X}{\partial s} \cdot \frac{1}{\theta_{1}}
$$

we can write

$$
\frac{\partial \Delta \omega}{\partial \Delta \lambda}=\frac{1}{\theta_{1}}\left(\frac{\partial \Delta v a}{\partial s}-\beta^{k} \cdot \frac{\partial \Delta k}{\partial s}-\beta^{l} \cdot \frac{\partial \Delta l}{\partial s}\right)
$$

plugging estimate from table 3

$$
\frac{\partial \Delta \omega}{\partial \Delta \lambda}=\frac{1}{\theta_{1}}\left(0.164-\beta^{k} \cdot 0.0902-\beta^{l} \cdot 0.00812\right)
$$

with $\theta_{1}>0$ it implies that:

$$
\beta^{k} \cdot 0.0902+\beta^{l} \cdot 0.00812<0.164 \Rightarrow \frac{\partial \Delta \omega}{\partial \Delta \lambda}=\alpha>0
$$

which holds for any plausible values of $\beta^{k}$ and $\beta^{l}$.

Furthermore, the effect of credit on value added are not mediated 
by other intermediate inputs, as shown by table A.1 in the appendix.

\subsection{Productivity Estimate}

Firms combine capital and labor to generate value added. We adopt a Hicks-neutral definition of productivity, and assume that output elasticities to input are sector-specific. Labor and capital are chosen after the company observes its specific value of productivity and constraints.

$$
v a_{i, t}=\omega_{i, t}+f^{s}\left(k_{i, t}, l_{i, t}\right)
$$

To obtain $\omega_{i, t}$ as in equation (6), we start by estimating sectorspecific (log)production functions $f^{s}\left(k_{i, t}, l_{i, t}\right)$ using various different assumptions. For this purpose, we follow Ackelberg et al (2006, ACF hereafter), and Wooldrige (2009), who build on the seminal works of Olley and Pakes (1996) and Levinsohn and Petrin (2003).

We consider either a Cobb-Douglas or a trans-log functional form for $f(\cdot){ }^{21}$ We use multiple proxy variables for estimation: expenditure in materials, expenditure in services and, in some specifications, capital growth rate. We allow labor (together with capital) to have dynamic implications, an essential feature of a production function in countries, like Italy, where labor market frictions are severe. We allow capital acquired in period $t$ to contribute to production immediately (a conservative assumption for our purposes), yet results are robust to impose that $K_{t}$ affects production at $t+1$ only. We use third order polynomials to approximate conditional expectations: this allows us to perform the estimate using a two-equations GMM (Wooldridge 2009).

\footnotetext{
${ }^{21}$ Cobb-Douglas and trans-log functions can be considered first- and second-order Taylor expansions of any smooth functional form.
} 
We do not observe firm-level input and output prices, consequently we have to rely on sector-level deflators. Thus, our measure of productivity is revenue-based, rather than quantity-based (Foster et al. 2008). This distinction may be relevant if, say, changes in credit constraints affect firm mark-up (e.g., because they are less able to invest in brand recognition and trade-mark registration, or to exert effort in seeking new profitable opportunities).

We also consider simpler specifications by imposing Cobb-Douglas and constant returns to scale. The elasticity of output to labor is estimated by the median labor share (cost of labor over value added) at sector level, ${ }^{22}$ or it is assumed equal to some default value $(0.75$, 0.67 , or 0.6 ). This (admittedly very simplistic) set of estimates are useful to show that results are not driven by specific estimation techniques. $^{23}$

Traditional production function estimation methods that rely on proxy variables require the assumption that productivity evolves exogenously. In our setting, we must assume that the past level of credit constraints $\lambda_{i, t-1}$ does not affect current productivity $\omega_{i, t}$, conditional on $\omega_{i, t-1},{ }^{24}$ which should not be assumed away in case the we detect an effect of contemporaneous $\lambda_{i, t}$ on $\omega_{i, t}$. Firms choices which affect productivity dynamics can be explicitly modeled if observed (as in Doraszelski and Jaumandreu (2013)). DeLocker (2013), studying learning-by-exporting, concludes that estimation of production function without considering the joint decisions of producing, investing and exporting might lead to bias estimate of the effect of entering a new market on productivity. We recognize the issue is present in our setting. Since we do not observe directly the firm-specific credit constraints (but only some exogenous shifter of them), we cannot estimate an endogenous productivity model,

\footnotetext{
${ }^{22}$ Which deliver consistent estimate for $f_{l}$ under the assumption of fully adjustable inputs.

${ }^{23}$ We also propose few measures of productivity based on net revenues rather than value added, estimated either following ACF or by cost shares for flexible inputs (labor, services and materials). Results, available upon request, are qualitatively similar but smaller in magnitude.

${ }^{24}$ That is, $\operatorname{Pr}\left[\omega_{i, t}=v \mid \omega_{i, t-1}, \lambda_{i, t-1}\right]=\operatorname{Pr}\left[\omega_{i, t}=v \mid \omega_{i, t-1}\right]$.
} 
including $\lambda_{i, t}$ itself. Therefore, we respond to the critique in a different way. Firstly, we notice that the the parameters estimated are still consistent under the null that productivity is unaffected by the credit shocks. ${ }^{25}$ Therefore, we can still perform a valid test of this null, ${ }^{26}$ (as long as standard errors are corrected for the multistage procedure), while the magnitudes should be interpreted with extreme caution. ${ }^{27}$ Furthermore, the results in previous section show that, at least in the simplest case (value added production function, Cobb-Douglas in labor and capital) any reasonable values for the elasticities leads us to the conclusion that credit constraints affect productivity. That is, as long as we are unwilling to allow for extremely high returns-to-scale (i.e. close to $200 \%$ ) of the value added function, then the effect on output of a change in credit constraints is too strong to be rationalized by the effect on the observed inputs alone; therefore, we conclude that, in any reasonable production function framework, productivity must be responding to credit supply.

\subsection{Effects on Productivity}

The estimation procedures described in the previous section provides sector-specific elasticity of value added to inputs. With them, we calculate productivity as a residual:

$$
\omega_{i, t}=v a_{i, t}-\widehat{\beta^{k}} k_{i, t}-\widehat{\beta^{l}} l_{i, t}
$$

and similarly for trans-log specification.

\footnotetext{
${ }^{25}$ As long as we can still use expenses in services and materials to proxy for unobserved productivity (inversion of the error). Notice that, according to the estimates presented in the previous section, slacker credit constraints accelerate capital accumulation, while keeping flexible inputs unchanged.

${ }^{26}$ Similarly, De Locker (2013) laments lack of power for the test, not wrong size.

${ }^{27}$ In particular, following De Locker(2013) intuition, we conjecture we might be underestimating the effect of credit constraints on productivity growth. In fact, slacker constraints (similarly to export in De Locker's paper) are related to larger investment and higher productivity growth, and its omission bias upward the capital coefficient and, consequently, downward the coefficient of $\lambda_{i, t}$ on productivity residual.
} 
Combining equations 8 and 11 we can write the log growth in productivity as a function of the shifter:

$$
\Delta \omega_{i, t}=\psi_{t}+\gamma s_{i, t}+\eta_{i, t}
$$

where

- $\gamma=\alpha \cdot \theta_{1}$

- $\eta_{i, t}=\Delta \tilde{\eta}_{i, t}+\alpha \epsilon_{i, t}$

- $\psi_{t}=\Delta \tilde{\psi}_{t}+\theta_{0} \alpha$ which represents time (or other) fixed effects

The error term $\eta_{i, t}$ collects firm specific characteristics which affect the growth rate of productivity $\left(\Delta \tilde{\eta}_{i, t}\right)$ or can improves firm ability to collect external funds $\left(\epsilon_{i, t}\right)$. If the procedure employed to separate firm and bank fixed effects on credit growth is valid, then the shifter captures only supply side variability and is uncorrelated with firm specific characteristics contained in $\eta_{i, t}{ }^{28}$. Consequently, we can estimate $\gamma$ by OLS. Since the analysis in previous sections suggest that the shifter has a positive effect on making the constraints slacker (i.e. $\theta_{1}>0$ ), then we can test the null hypothesis $H_{0} \alpha=0$ (or $\alpha \leq 0$ ) by testing $\gamma=0$ (or $\gamma \leq 0$ ).

Therefore, to investigate the effect of credit shocks on productivity, we perform OLS on the model:

$$
\Delta \omega_{i, t}=\psi_{t}+\psi_{i}+\gamma s_{i, t}+\eta_{i, t}
$$

where $s_{i, t}$ is our supply credit shifter and $\psi_{t}, \psi_{i}$ are year and firm fixed effects. Each observation is an Italian manufacturing firm for one year, from 1998 to 2012. Results are presented in table 4 below. We repeat the exercise for seven different series of $\omega_{i, t}$, each computed with a different methodology: columns from (1) to (4) use parameters estimated with ACF methods, as previously explained,

\footnotetext{
${ }^{28}$ For more discussion on the potential source of correlation between $\Delta \eta_{i, t}$ and $s_{i, t}$, such as assortative matching, see section about instrumental variables approach
} 
using either Cobb-Douglas or Trans-Log functional form and different set of proxies. Columns (5)-(7) use "Solow residual" as dependent variables, imposing different elasticity of value added to capital.

The estimated effects of credit supply expansion on productivity growth is positive and statistically significant. A one standard deviation increase in the shifter leads to about half of percentage point increase in productivity, which is equivalent to about $1.4 \%$ of its standard deviation. Using the results in table 2 we can interpret the magnitude in an alternative way: the same supply shocks which is needed to increase total granted credit by $1 \%$ increases productivity by around one tenth of a percentage point. It is interesting to notice that the results are very similar across different series of productivity estimates. Moreover, results are almost unchanged if we include the usual set of lagged controls (third degree polynomial in capital, value to capital, liquidity to capital and cash flow to capital ratios) as shown in table A.1 in the appendix.

\section{The Interbank Market Collapse as a Credit Supply Shock in Italy}

The credit supply shifter $s_{i, t}$ has the value of being general, in that it can be attributed to all firms (both multiple and single-borrowers) and measured in all years for which there is bank-firm data on credit granted. Yet, as discussed in Section 4, this generality comes at the expenses of several assumptions which allow the shifter to be orthogonal to credit demand.

An alternative strategy is to look for a specific "natural experiment" in which credit supply shifts are arguably exogenous with respect to firm demand. The interbank market represents a critical source of funding for banks: it allows them to readily fill liquidity needs of different maturities through secured and unsecured con- 
Table 4: Effects of Credit shifter on Productivity growth

\begin{tabular}{|c|c|c|c|c|c|c|c|}
\hline VARIABLES & $\begin{array}{c}(1) \\
\Delta \omega_{i, t}\end{array}$ & $\begin{array}{c}(2) \\
\Delta \omega_{i, t}\end{array}$ & $\begin{array}{c}(3) \\
\Delta \omega_{i, t}\end{array}$ & $\begin{array}{c}(4) \\
\Delta \omega_{i, t}\end{array}$ & $\begin{array}{c}(5) \\
\Delta \omega_{i, t}\end{array}$ & $\begin{array}{c}(6) \\
\Delta \omega_{i, t}\end{array}$ & $\begin{array}{c}(7) \\
\Delta \omega_{i, t}\end{array}$ \\
\hline$s_{i, t}$ & $\begin{array}{c}0.116^{* * *} \\
(0.0292)\end{array}$ & $\begin{array}{c}0.131^{* * *} \\
(0.0261)\end{array}$ & $\begin{array}{c}0.141^{* * *} \\
(0.0259)\end{array}$ & $\begin{array}{c}0.159^{* * *} \\
(0.0279)\end{array}$ & $\begin{array}{c}0.135^{* * *} \\
(0.0243)\end{array}$ & $\begin{array}{c}0.129^{* * *} \\
(0.0246)\end{array}$ & $\begin{array}{c}0.123^{* * *} \\
(0.0250)\end{array}$ \\
\hline Firm FEs & $\mathrm{Y}$ & $\mathrm{Y}$ & $\mathrm{Y}$ & $\mathrm{Y}$ & $\mathrm{Y}$ & $\mathrm{Y}$ & $\mathrm{Y}$ \\
\hline Year FEs & $\mathrm{Y}$ & $\mathrm{Y}$ & $\mathrm{Y}$ & $\mathrm{Y}$ & $\mathrm{Y}$ & $\mathrm{Y}$ & $\mathrm{Y}$ \\
\hline Prod. Function & $\mathrm{T}-\mathrm{L}$ & C-D & $\mathrm{T}-\mathrm{L}$ & $\mathrm{T}-\mathrm{L}$ & C-D (CRS) & C-D (CRS) & C-D (CRS) \\
\hline Estimation of $\omega_{i, t}$ & $\mathrm{ACF}$ & $\mathrm{ACF}$ & $\mathrm{ACF}$ & $\mathrm{ACF}$ & $\begin{array}{c}\text { Assumed } \\
\beta_{k}=.25\end{array}$ & $\begin{array}{c}\text { Assumed } \\
\beta_{k}=.33\end{array}$ & $\begin{array}{c}\text { Assumed } \\
\beta_{k}=.40\end{array}$ \\
\hline Proxy vars & mat, serv & mat, serv & mat & mat, serv, $\Delta k_{i, t}$ & & & \\
\hline Observations & 222629 & 222629 & 222629 & 222629 & 222629 & 222629 & 222629 \\
\hline 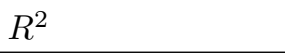 & 0.164 & 0.177 & 0.184 & 0.167 & 0.184 & 0.188 & 0.191 \\
\hline
\end{tabular}

tracts. Total gross interbank funding represented over $13.3 \%$ of total assets of Italian banks at the end of 2006. Market transactions begun shrinking in July 2007, when fears about the spread of toxic assets in banks' balance-sheets made the evaluation of counterparty risk extremely difficult (Brunnermeier 2009); the situation worsened further after Lehman's default in September 2008. As a consequence, total transactions among banks fell significantly. In Italy, in particular, they plummeted from 24bn. Euros in 2006 to 4.8bn. at the end of 2009. At the same time, the cost of raising funds in the interbank market rose sharply: the Euribor-Eurepo spread, which was practically zero until August 2007, reached over 50 basis points for all maturities in the subsequent year; it then increased by 5 times after the Lehman crisis, and remained well above 20 basis points in the following years.

Some recent papers have exploited the collapse of the interbank market as a source of exogenous shock to credit supply. They found 
that bank pre-crisis exposure to the interbank shock, as measured by the ratio between interbank liabilities and assets, was a significant predictor of a drop in credit granted during the crisis (Iyer et al. 2014), and that this drop had a significant negative effect on firm's capital accumulation (Cingano et al. 2016). They also report several empirical tests showing that bank pre-crisis exposure was not correlated with its borrowers' characteristics, such as investment opportunities and firm growth potential, thus making this variable particularly suitable to instrument the impact of credit supply on firm's outcomes.

We focus on the period 2007-2009. Our measure of firm exposure to the credit supply tightening is the average 2006 interbank exposure of Italian banks at the firm level, using firm's specific credit shares in 2006 as weights. Because firm exposure is time-invariant, we cross-sectional observations over the three years window. We add year times sector times province FEs. Formally, for each firm $i$ active in industry $s$ and province $p$ over the years $t \in[2007,2009]$, we estimate the model:

$$
\Delta D V_{i, p, s, t}=\sigma_{0}+\sigma_{1} I N T B K_{i, 2006}+\psi_{p, s, t}+\varepsilon_{i, p, s, t}
$$

where the dependent variable is either firm inputs and output, or various measures of productivity.

In Table 5, we provide results of the impact of interbank shock on input accumulation and output growth. Similarly to the results using the general credit supply shifter, the impact on value added is stronger than the one on inputs. Also, among the two inputs considered, the main effect is found on capital accumulation, while the one on employment is not statistically different from zero.

Table 6 display the estimated impact of the interbank shock on productivity, using several different estimates of Hicks-neutral efficiency: as in the previous Section, we consider different production functions (Trans-Log, Cobb-Douglas, and Cobb-Douglas with con- 
Table 5: Effect of Interbank Shock on Value Added, Capital, and Employment Yearly Growth Rates (Years 2007-2009)

\begin{tabular}{lccc}
\hline & $(1)$ & $(2)$ & $(3)$ \\
Dependent Variable & $\Delta v a_{i, t}$ & $\Delta k_{i, t}$ & $\Delta l_{i, t}$ \\
\hline \multirow{N}{*}{$\bar{T} B K_{i, 2006}$} & $-0.144^{* * *}$ & $-0.063^{*}$ & -0.027 \\
& $(0.049)$ & $(0.039)$ & $(0.033)$ \\
& & & \\
Year $\times$ Province & $\mathrm{Y}$ & $\mathrm{Y}$ & $\mathrm{Y}$ \\
$\times$ Sector FEs & $\mathrm{Y}$ & $\mathrm{Y}$ & $\mathrm{Y}$ \\
Observations & 38058 & 38058 & 38058
\end{tabular}

stant returns-to-scale) and different proxy variables for identification (only materials; materials and services; materials, services, and the lagged growth rate of capital).

Results show that a 1 percentage point increase in average pre-crisis interbank-to-assets ratio is associated with a yearly drop in productivity growth ranging from -0.1 to -0.2 percentage points. All in all, the results are remarkably similar to those obtained using the general supply shifter. 


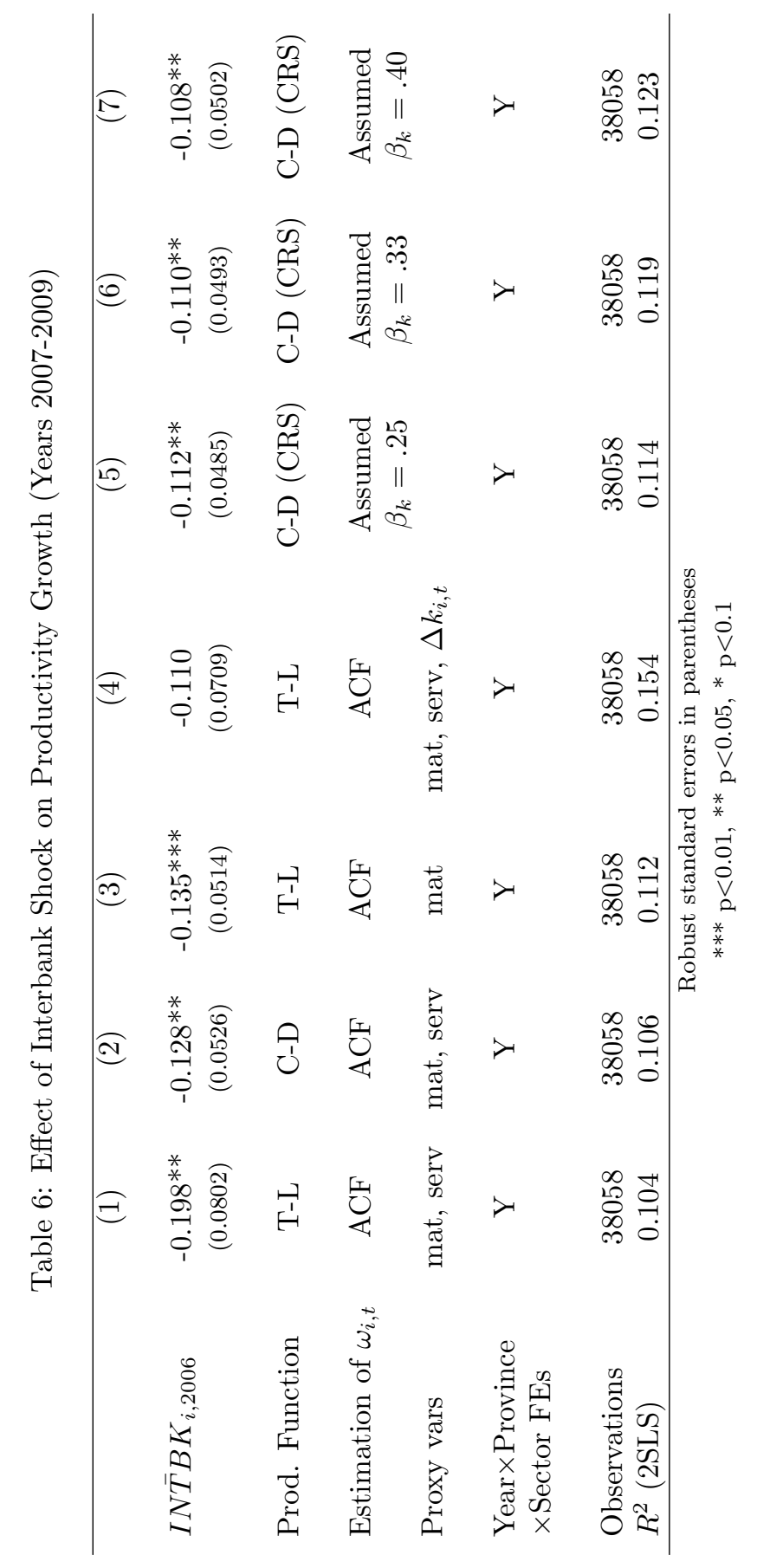




\section{Robustness}

We perform a series of additional robustness test to strengthen our results. Results are, in most cases, not sensitive to the use of different productivity series.

\subsection{Granular Borrowers}

The presence of "granular" firms can be a concern for the exclusion restriction of $s_{i, t}$ from equation 15: companies big enough to constitute a large share of the portfolio of loans of a bank can directly affect the financial health of such financial institution. Therefore, we repeat our baseline estimates by applying a strict selection rule: we drop any firm which at any point in time receive credit from any bank for an amount above $1 \%$ of the total credit granted by that same financial institution. Results are presented in table A.1 which shows that parameters are extremely similar to the version including the whole sample, both in size that in statistical significance.

\section{2 $\quad$ Fixed Effects Structure}

In the main specification we employ firm fixed effects to control for firm heterogeneity that might be correlated with both credit shocks and productivity growth. To check that this choice is not entirely driving the results, we repeat the estimation procedure with a variety of FEs structures. Results are presented in table 18, which employs residual from Cobb-Douglas production function ${ }^{29}$. Column (1) includes only year FEs, while column (2) add province FEs. Column (3) includes, beside firm FEs, a year times sector times province FEs: it is supposed to capture business cycle specific to industries and geographic areas. Column (4) is the baseline estimate. Any structure delivers the same result about the positive and significa-

\footnotetext{
${ }^{29}$ Estimation is performed following ACF procedure, and using services and materials expenditure as proxy variables.
} 
tive effect of the credit shifter on productivity growth. However, the size of the coefficient is affected by the estimator: in particular, using only within firm variance to estimate the parameters increases the coefficients.

\subsection{Lending to Clients, Lending to Supplier}

Another important possible source of endogeneity is the direct effect of banks' credit shocks on firms' demand. For instance, if there is positive correlation between clients' and suppliers' lenders, then when any bank contracts its supply of credit, it affects a borrower both through the cuts to its credit and by the diminished amount of credit given to its client.

Why should clients and suppliers to borrow from the same lender? Bank might focus in supplying a particular value chain for two main reasons: first, because of geographical and sector specialization, which our fixed effects (province and 2-digit industry) might be too coarse to capture. Secondly, there might be economy of scope in acquiring information about firms operating in strong interconnection.

To investigate whether the causal effect we have been underlying acts through firms improved ability to produce and sell their product (value added productivity) rather than from direct effect of credit shocks on companies demand, we perform a simple heterogeneity exercise: we investigate how the effect of the credit shocks vary between firms with different export orientation. In fact, when firms sell abroad, is much less likely that they might borrow from the same banks than their clients. More generally, these firms are less likely to be exposed to local demand shocks. We calculate the share of export over revenue

$$
\frac{\text { export }_{i, t}}{y_{i, t}}
$$

and we interact it with the credit supply shifter, estimating the model: 


$$
\Delta \omega_{i, t}=\psi_{t}+\psi_{i}+\gamma_{0} s_{i, t}+\gamma_{1} \frac{\text { export }_{i, t-2}}{y_{i, t-2}}+\gamma_{2} s_{i, t} \cdot \frac{\text { export }_{i, t-2}}{y_{i, t-2}}+\eta_{i, t}
$$

the parameter $\gamma_{2}$ is informative on how the shocks has different effects according to firms export propensity. We use lagged values for export propensity to avoid additional endogeneity issues. Results are presented in tables 19 and 20, in the appendix, where productivity is estimated, respectively, assuming Cobb-Douglas or Trans-Log production function. Columns (4) to (6) in each table repeat the exercise by using a dummy variable equal to one if firm $i$ generated more than half of its revenue abroad.

We cannot reject the null that $\gamma_{2}=0$ in any specification: results indicates that firms more export-intensive are not differently affected by the credit supply shock. Therefore, we can reasonably reject the concern that the effect of credit shifter on firms capacity to generate value added comes from a direct effect on firms' clients capacity to finance purchases of intermediate inputs.

\section{Heterogeneity, Persistence and Possible Mech- anisms}

After showing that supply-side shocks to credit constraints affect productivity we ask whether the effect is mainly driven by expansion or contractions. Is productivity harmed when constraints get tighter or does productivity benefit when they become slacker? For this reason we estimate the model:

$$
\Delta \omega_{i, t}=\psi_{t}+\psi_{i}+\gamma s_{i, t}+\gamma_{n e g} s_{i, t} \cdot \mathbf{1}\left[s_{i, t}<0\right]+\eta_{i, t}
$$

Moreover, we want to know whether the effect we detect is mainly or solely driven by the financial and economic crisis of the late 2000's. We, consequently estimate: 


$$
\Delta \omega_{i, t}=\psi_{t}+\psi_{i}+\gamma s_{i, t}+\gamma_{p r e 2007} s_{i, t} \cdot \mathbf{1}[t<2007]+\eta_{i, t}
$$

Finally, we ask whether small and large firms are affected in different manner by the supply-side credit shocks. We divide firms by quartile according to lagged capital, then we run:

$\Delta \omega_{i, t}=\psi_{t}+\psi_{i}+\gamma s_{i, t}+\gamma_{\text {interaction }} s_{i, t} \mathbf{1}\left[k_{t-2} \in Q_{4, t-2}\right]+\gamma_{Q_{4}} \mathbf{1}\left[k_{t-2} \in Q_{4, t-2}\right]+\eta_{i, t}$

where $Q_{4, t-2}$ is the upper quartile of firms' capital distribution in year $t-2$.

Table 7 below uses residuals from Cobb-Douglas to measure productivity and show that the effect is symmetric around zeros: tightening of credit constraints have no larger effects than expansion nor vice-versa. We also find that the effect is not statistically different before 2007 than from 2007 on: it was present before the credit crunch and the following financial crisis. ${ }^{30}$ As for the role of size, we find that the effect of credit supply shocks is significantly lower for firms in the upper quartile of the capital distribution. ${ }^{31}$ This might be due either to bigger firms having better ability to substitute away from lenders contracting credit supply or to banks being more reluctant to cut loans and credit lines to larger borrowers.

Then, we investigate heterogeneity between different industries: we repeated the estimation procedure sector by sector. Four industries seems to be the main driver of the positive effect of credit supply on productivity: production of vehicles (car excluded), production of electrical appliance (and non electrical home appliance), production of metal manufactures, and textile production. ${ }^{32}$

Finally, we investigate the persistence of the effect on productiv-

\footnotetext{
${ }^{30}$ The test is also showing that the change in threshold to be registered in the Credit Register, which happened in 2009 (from $75 \mathrm{k}$ to $35 \mathrm{k}$ ), is not affecting our results.

${ }^{31}$ The effect on this subsample is actually not different from zero, as we show in a separate regression whose results are available upon request.

${ }^{32}$ Results available upon request.
} 
Table 7: Heterogeneity (C-D)

\begin{tabular}{|c|c|c|c|}
\hline VARIABLES & $\begin{array}{c}(1) \\
\Delta \omega_{i, t}\end{array}$ & $\begin{array}{c}(2) \\
\Delta \omega_{i, t} \\
\end{array}$ & $\begin{array}{c}(3) \\
\Delta \omega_{i, t} \\
\end{array}$ \\
\hline$s_{i, t}$ & $\begin{array}{c}0.109^{* * *} \\
(0.0384)\end{array}$ & $\begin{array}{c}0.115^{* * *} \\
(0.0395)\end{array}$ & $\begin{array}{c}0.178^{* * *} \\
(0.0337)\end{array}$ \\
\hline$s_{i, t} \cdot \mathbf{1}\left[s_{i, t}<0\right]$ & & $\begin{array}{l}0.0414 \\
(0.0806)\end{array}$ & \\
\hline$s_{i, t} \cdot \mathbf{1}\left[k_{i, t-2} \in Q_{t}\right]$ & & & $\begin{array}{c}-0.111^{* *} \\
(0.0473)\end{array}$ \\
\hline $\mathbf{1}\left[k_{i, t-2} \in Q_{t-2}\right]$ & & & $\begin{array}{r}-0.00257 \\
(0.00239)\end{array}$ \\
\hline$s_{i, t} \cdot \mathbf{1}[t<2007]$ & $\begin{array}{c}0.0396 \\
(0.0450)\end{array}$ & & \\
\hline Year FEs & $\mathrm{Y}$ & $\mathrm{Y}$ & $\mathrm{Y}$ \\
\hline Firm FEs & $\mathrm{Y}$ & $\mathrm{Y}$ & $\mathrm{Y}$ \\
\hline Observations & 222629 & 222629 & 222629 \\
\hline$R^{2}$ & 0.177 & 0.177 & 0.177 \\
\hline
\end{tabular}

ity by running OLS on the models:

$$
\Delta \omega_{i, t}=\psi_{t}+\psi_{i}+\sum_{\tau=0}^{3} s_{i, t-\tau} \gamma_{\tau}+\eta_{i, t}
$$

and

$$
\omega_{i, t}=\psi_{t}+\psi_{i}+\sum_{\tau=0}^{3} s_{i, t-\tau} \gamma_{\tau}+\eta_{i, t}
$$

Tables 21 and 22 in the appendix contain the resulting estimates. The former table uses residual from Cobb-Doubglas ${ }^{33}$ estimate of production function, while the latter is based on Trans-Log estimation $^{34}$. We include also lagged values of the dependent variable in

\footnotetext{
${ }^{33}$ Materials and Services as proxies

${ }^{34}$ Materials, Services and $\Delta k_{i, t}$ as proxies
} 
columns (2) and (4) of each table. Two patterns clearly arises from the data. First, the effect on productivity growth is not permanent: the effects of the shifters show a partial 'rebound' (negative coefficient at past lags - columns 1 and 2). This result is consistent with firms being able to "save out of credit constraints" over time (Moll 2014). Second, the increase in productivity is persistent: the coefficient on productivity levels (log) is positive and significant for several lags (columns 3 and 4). Moreover, the 'rebound' noticed on growth rate is not of the same size of the contemporaneous effect.

\subsection{Possible Channels}

We look for empirical evidence about the possible mechanisms linking credit frictions and productivity. In particular, we are able to test three different, non-alternative, channels: ITC adoption, R\&D expenditures, and export orientation. Notice that these are only three of many potential mechanisms: for instance, it may be that slacker credit constraints allow for timely quality upgrading of new products in the face of new market opportunities, or they help firm in building consumer confidence through marketing and advertisements, or improving the quality of the workforce. We leave testing other potential channels to future research.

Information on ITC adoption is available from INVIND, a survey conducted by Bank of Italy on services and manufacturing companies, for the years 1999-2001. ${ }^{35}$ We consider two variables: the number of PC per employee and the number of PC per 1,000 euros of capital. We estimate the baseline model either on the whole INVIND sample, or excluding the top-quartile firms by size (because we have found that very large firms are much less hit by credit shocks). Table 8 presents results from the resulting four specifications. The shifter seems positively correlated with the two measures of ITC adoption, but the impact is not statistically different from

\footnotetext{
${ }^{35}$ Speed of adoption of ITC technology caused large difference in productivity between US and European companies, as shown by Bloom et al (2012).
} 
Table 8: Credit Supply shifter on ITC adoption and utilization rate

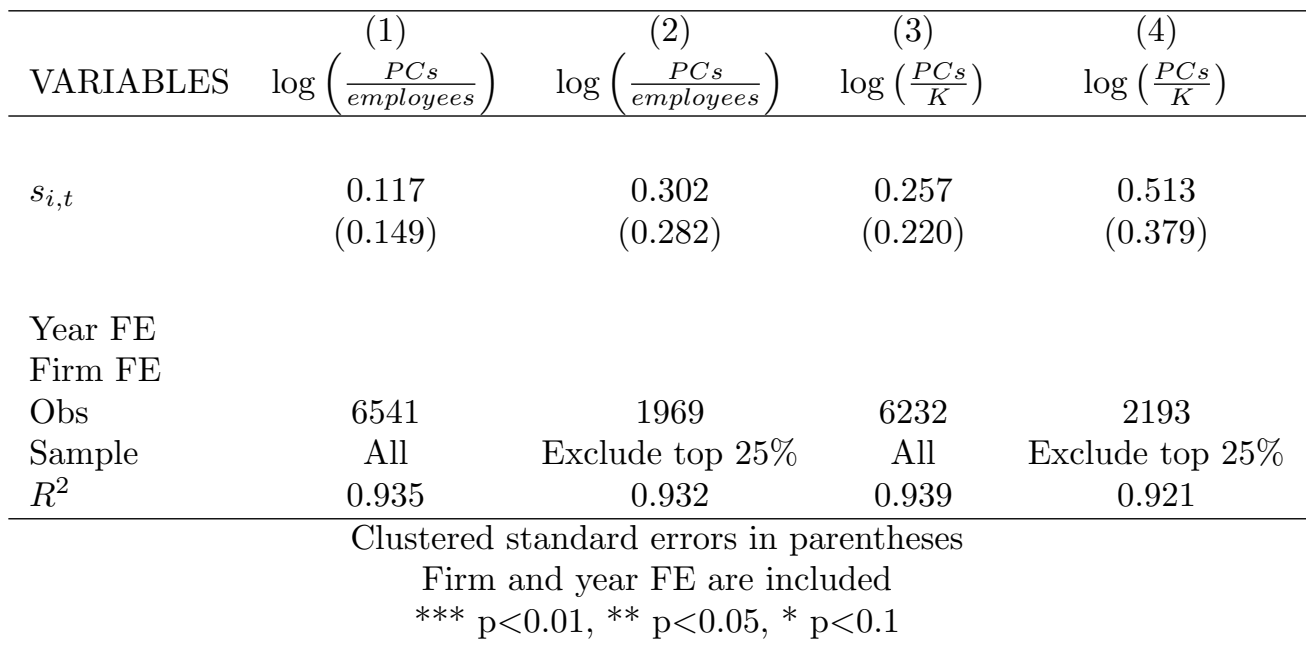

zero (possibly because of the small sample size).

Moreover, we find a positive and significant effect of supply-side shocks on self-declared capital utilization, which might indicate that factors' hoarding plays a role as amplification mechanism. ${ }^{36}$

INVIND survey is also used to identify firms who engage in export and in R\&D expenditures. We consider dichotomic variables for the extensive margin of both activities. For what regards $R \& D$ expenditures, we have two different variables: one which solely elicits R\&D is available only for three waves of INVIND, the other is available over the period 2001-2013, yet includes both R\&D and marketing. Results presented in Table 9 show that there is a positive and significant effect of the credit shifter on the propensity to perform R\&D activities and to engage in export.

\footnotetext{
${ }^{36}$ However, expenditure on flexible inputs do not respond to credit shocks and, consequently, we might not give too much weight on this self-declared measure of factor utilization.
} 
Table 9: Credit Supply shifter on ITC adoption and utilization rate

\begin{tabular}{|c|c|c|c|}
\hline VARIABLES & $\begin{array}{c}(1) \\
\text { Expt }_{i, t}\end{array}$ & $\begin{array}{c}(2) \\
R \& D_{i, t}\end{array}$ & $\begin{array}{c}(3) \\
R D \& E t a l_{i, t}\end{array}$ \\
\hline$s_{i, t}$ & $\begin{array}{l}0.152^{*} \\
(0.085)\end{array}$ & $\begin{array}{l}0.238^{*} \\
(0.128)\end{array}$ & $\begin{array}{l}-0.064 \\
(0.105)\end{array}$ \\
\hline $\begin{array}{l}\text { Year FE } \\
\text { Firm FE } \\
\text { Obs }\end{array}$ & 13.249 & 5.991 & 15,177 \\
\hline
\end{tabular}

\section{Conclusions}

The evidence presented in this paper indicates that credit constraints do not only limit the amount of inputs that each firm can acquire ceteris paribus, but also harm their ability to generate value added for a given amount of inputs. Equivalently, this empirical investigation shows that a share of the heterogeneity measured in firms productivity is caused by heterogeneity in access to external funding.

We exploit information about bank-firms credit relations to create a supply-side shifter of credit constraints, following the intuition of the "lending channel": firms connected to banks which contract (expand) the supply of credit experience a tightening (loosening) of their credit constraints. We show that this shifter does not only affect firms acquisition of capital, but also its value added productivity, as estimated by standard techniques. We perform several robustness exercises, to show that our findings are not driven by correlation between lenders and borrowers' performance. In particular, we enrich our analysis with two different instrumental variable approaches taken from the previous literature (dependence of lenders from Interbank mkt and merger and acquisition episodes), to control for assortative matching or other possible source of en- 
dogeneity. The instrumented estimates of the effect of supply-side shocks on productivity are still positive and statistically significant. Moreover, they are substantially larger than their OLS counterpart. We interpret this finding as evidence that, if any endogeneity issues is biasing our baseline estimates, this is dampening our coefficients.

We study heterogeneity and persistence of the effect we detect. We show that the effect is symmetric around zero: it is not driven solely by contraction. The effect is present with the magnitude before the credit crunch and the following economic crisis. Moreover, we show that firms in the upper quartile of size distribution are unaffected by the credit supply contraction. Finally, we show that the effect of a credit shock on productivity is persistent but not permanent.

The paper shows that it is not only the quantity of capital acquired that matter, but also the power to implement opportune investment at the right time (to exploit new opportunities) and the freedom to choose the best productive structure without concern from possible lack of external funds. 


\section{References}

1. Accetturo A., A. Bassanetti, M. Bugamelli, I. Faiella, P. Finaldi Russo, D. Franco, S. Giacomelli, and M. Omiccioli (2013) "The Italian industrial system between globalization and crisis", Bank of Italy Occasional Papers no. 193.

2. Acemoglu D., P. Aghion, and F. Zilibotti (2006), "Distance to Frontier, Selection, and Economic Growth", Journal of the European Economic Association, 4(1), 37-74.

3. Ackerberg, D.A., C. Lanier Benkard, S. Berry, and A. Pakes (2007) "Econometric Tools for Analyzing Market Outcomes", in "Handbook of Econometrics".

4. Aghion P., P. Askenazy, N. Berman, G. Cette, and L. Eymard (2012), Credit Constraints and the Cyclicality of R\&D Investment: Evidence from France, Journal of the European Economic Association, 10(5), 1001-1024.

5. Amiti M. and D.E. Weinstein (forthcoming) "How Much do Idiosyncratic Bank Shocks Affect Investment? Evidence from Matched Bank-Firm Data", Journal of Political Economy

6. Amiti M. and D.E. Weinstein (2011) "Exports and Financial Shocks" Quarterly Journal of Economics, 126(4), 1841-1877.

7. Bartelsman E., J. Haltiwanger, and S. Scarpetta (2013) "CrossCountry Differences in Productivity: The Role of Allocation and Selection" American Economic Review, 103(1), 305-334.

8. Bentolila S., M., Jansen, G. Jimenez, and S. Ruano (2015) "When Credit Dries Up: Job Losses in the Great Recession", CEMFI Working Paper no. 1310.

9. Benkard C. Lanier (2000) "Learning and Forgetting: The Dynamics of Aircraft Production", American Economic Review, 90(4), 1034-1054. 
10. Bloom N., R. Sadun, and J. Van Reenen (2012) "Americans Do IT Better: US Multinationals and the Productivity Miracle", American Economic Review, 102(1), 167-201.

11. Bottero M., S. Lenzu and, F. Mezzanotti (2015) "Sovereing Debt Exposure and the Bank Lending Channel: Impact on Credit Supply and the Real Economy", Bank of Italy Working Paper no. 1032.

12. Buono I. and Formai (2016) "The Heterogenenous Response of Domestic Sales and Exports to Bank Credit Shocks", Bank of Italy Working Paper no. 1066..

13. Caggese A. (2016) "Financing Constraints, Radical versus Incremental Innovation, and Aggregate Productivity", CREI Working Paper no. 865.

14. Chodorow-Reich G. (2014) "The Employment Effects of Credit Market Disruptions: Firm-level Evidence from the 2008-09 Financial Crisis" Quarterly Journal of Economics, 129(2014), 159.

15. Cingano F., F. Manaresi, and E. Sette (2016) "Does credit crunch investments down? New evidence on the real effects of the bank-lending channel", Review of Financial Studies, 29(10), $2737-2773$.

16. Doraszelski and Jaumandreu (2013), "R\&D and productivity: Estimating endogenous productivity", Review of Economic Studies, 80(4), 1338-1383.

17. De Loecker J. (2011), "Product Differentiation, Multi-Product Firms and Estimating the Impact of Trade Liberalization on Productivity", Econometrica, 79(5), 1407-1451.

18. De Loecker J. (2013), "Detecting Learning by Exporting" American Economic Journal: Microeconomics, 5(3), 1-21.

RAND Journal of Economics, 44(2), 249-274. 
19. Fazzari S.M., G. Hubbard, and B.C. Petersen (1988) "Financing Constraints and Corporate Investment" Brooking Papers on Economic Activity.

20. Foster L., J. Haltiwanger, and C. Syverson (2008) "Reallocation, Firm Turnover, and Efficiency: Selection on Productivity or Profitability" American Economic Review, 98(1), 394-425.

21. Garcia-Macia D. (2015) "The Financing of Ideas and the Great Deviation", mimeo

22. Gine X. and D. Yang (2009), "Insurance, Credit, and Technology Adoption: Field Experimental Evidence from Malawi" Journal of Development Economics, 8(1), 1-11.

23. Gopinath G., S. Kalemli-Ozcan, L. Karabarbounis, and C. Villegas-Sanchez (2015) "Capital Allocation and Productivity in South Europe", NBER Working Paper no. 21453.

24. Hsieh C.T. and P.J. Klenow (2009) "Misallocation and Manufacturing TFP in China and India", Quarterly Journal of Economics, 124(4), 1403-1448.

25. Iyer, Lopes, Peydro and Schoar (2014), "Interbank Liquidity Crunch and the Firm Credit Crunch: Evidence from the 2007-2009 Crisis", Review of Financial Studies

26. Khwaja A.I. and A. Mian (2008) "Tracing The Impact of Bank Liquidity Shocks ", American Economic Review, 98(4), 14131442.

27. Jiménez, Ongena, Peydró and Saurina (2012) "Credit Supply and Monetary Policy: Identifying the Bank Balance-Sheet Channel with Loan Applications" American Economic Review

28. Jorda, Schularick and Taylor (2012) "When Credit Bites Back: Leverage, Business Cycles, and Crises", Federal Reserve Bank of San Francisco. 
29. Meza F. and E. Quintin (2007), Factor Utilization and the Real Impact of Financial Crises, the B.E. Journal of Macroeconomics, $7(1)$.

30. Midrigan and Xu (2013) "Finance and Misallocation: Evidence from Plant-Level Data", American Economic Review

31. Moll (2014) "Productivity Losses from Financial Frictions: Can Self-financing Undo Capital Misallocation?", American Economic Review

32. Lazear E.P. (2000) "Performance Pay and Productivity", American Economic Review, 90(5), 1346-1361.

33. Levinsohn and Petrin (2003) "Estimating Production Functions Using Inputs to Control for Unobservables", Review of Economic Studies

34. Lenzu, S. and F. Manaresi (2017) "Credit Over the Cycles", mimeo.

35. Olley and Pakes (1996) "Dynamics of Productivity in the Telecommunications Equipment Industry", Econometrica

36. Paravisini, Rappoport, P. Schnabl, and D. Wolfenzon (2014) "Dissecting the Effect of Credit Supply on Trade: Evidence from Matched Credit-Export Data", Review of Economic Studies, 82(1), 333-359.

37. Rauh J. (2006) "Investment and Financing Constraints: Evidence from the Funding of Corporate Pension Plans", Journal of Finance, 61(1), 33-71.

38. Reinhart and Rogoff (2009) "The Aftermath of Financial Crises ", American Economic Review

39. Schnabl P. (2012) "The International Transmission of Bank Liquidity Shocks: Evidence from an Emerging Market", Journal of Finance, 67(3), 897-932. 
40. Syverson C. (2011) "What Determines Productivity?" Journal of Economic Literature, 49(2), 326-365.

41. Wooldridge J. (2009) "On estimating firm-level production functions using proxy variables to control for unobservables", Economic Letters 
Table 10: Descriptive Statistics: logs

\begin{tabular}{lccccc}
\hline & $\begin{array}{c}(1) \\
\text { Value } \\
\text { Added }\end{array}$ & $\begin{array}{c}(2) \\
\text { Capital }\end{array}$ & $\begin{array}{c}(3) \\
\text { Wage } \\
\text { Bill }\end{array}$ & $\begin{array}{c}(4) \\
\text { Expenditure } \\
\text { for Materials }\end{array}$ & $\begin{array}{c}(5) \\
\text { Expenditure } \\
\text { for Services }\end{array}$ \\
mean & 7.7 & 7.8 & 2.3 & 8.4 & 7.6 \\
median & 7.7 & 7.9 & 2.3 & 8.4 & 7.6 \\
sd & 1.3 & 1.5 & 1.3 & 1.5 & 1.2 \\
$\mathrm{~N}$ & & & & 203790 & 22608 \\
\hline \multicolumn{5}{r}{ Years 1998-2012. Values are in logs of thousands of 2010 euros }
\end{tabular}

Figure 1: Distribution of Credit Supply Shifter

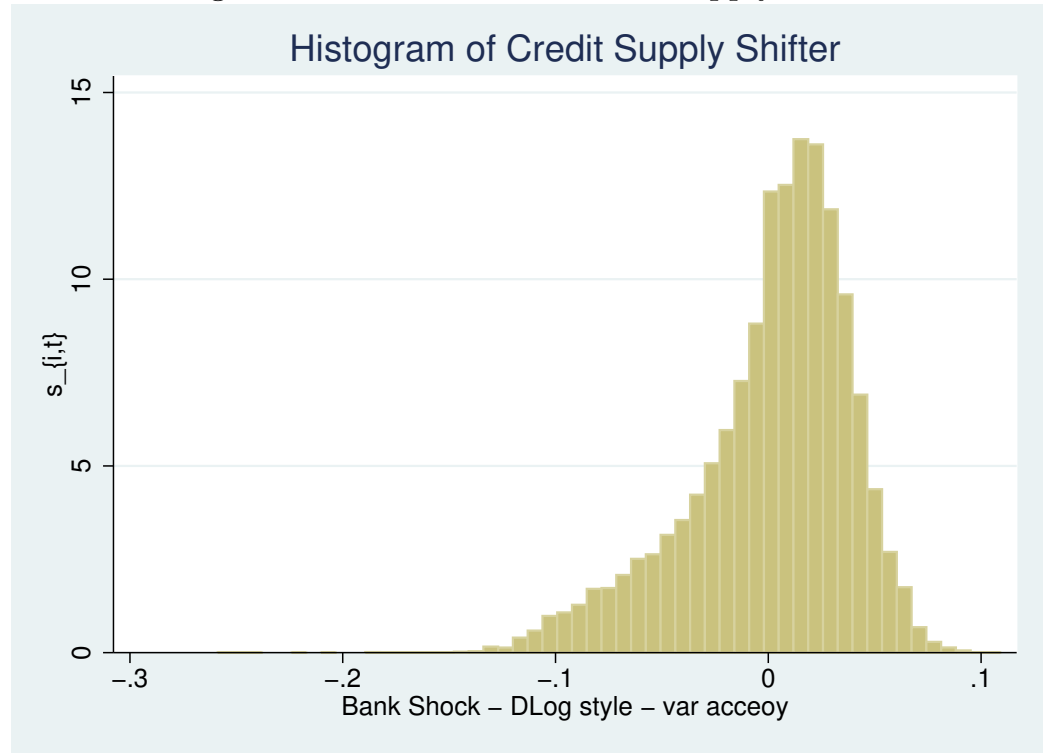

\section{A Appendix}

\section{A.1 Results of Productivity Estimation}

Table 13 below presents the mean of the parameter estimates, where averages are taken weighting each sector by number of firms. Using a Cobb-Douglas production function, we estimate slightly declining returns-to-scale, with labor elasticity of value added at 0.66 , and capital elasticity at around 0.28. 
Table 11: Descriptive Statistics: delta logs

\begin{tabular}{lcccc}
\hline & $(1)$ & $(2)$ & $(3)$ & $(4)$ \\
& $\Delta v a_{i, t}$ & $\Delta k_{i, t}$ & $\Delta l_{i, t}$ & $\Delta^{2} k_{i, t}$ \\
\hline mean & -.005 & .015 & .069 & -.027 \\
median & .015 & .016 & -.002 & -.006 \\
sd & .363 & .201 & .237 & .335 \\
& & & & 222629 \\
$\mathrm{~N}$ & 222629 & 222629 & 222629 & 2010 euros
\end{tabular}

Table 12: Credit Register - Descriptive Statistics

\begin{tabular}{|c|c|c|c|c|c|c|}
\hline Year & $\begin{array}{c}\text { No. of Banks } \\
\text { per Firm }\end{array}$ & $\begin{array}{l}\text { No. of } \\
\text { Firms }\end{array}$ & $\begin{array}{l}\% \text { Firms with } \\
\text { Multiple Banks }\end{array}$ & $\begin{array}{c}\text { Mean Granted } \\
\text { Credit }\end{array}$ & $\begin{array}{l}\text { No. of Firms } \\
\text { per Bank }\end{array}$ & $\begin{array}{l}\text { No. of } \\
\text { Banks }\end{array}$ \\
\hline 1998 & 2.9 & 860 & $57 \%$ & 398 & 860 & 1053 \\
\hline 1999 & 3.0 & 920 & $57 \%$ & 427 & 920 & 1047 \\
\hline 2000 & 2.9 & 997 & $57 \%$ & 462 & 997 & 1013 \\
\hline 2001 & 3.1 & 1132 & $60 \%$ & 461 & 1132 & 1003 \\
\hline 2002 & 3.0 & 1178 & $58 \%$ & 503 & 1177 & 992 \\
\hline 2003 & 2.8 & 1176 & $56 \%$ & 535 & 1176 & 994 \\
\hline 2004 & 2.8 & 1224 & $55 \%$ & 558 & 1224 & 985 \\
\hline 2005 & 2.8 & 1269 & $55 \%$ & 588 & 1269 & 992 \\
\hline 2006 & 2.7 & 1308 & $55 \%$ & 640 & 1307 & 1008 \\
\hline 2007 & 2.8 & 1366 & $55 \%$ & 655 & 1366 & 1025 \\
\hline 2008 & 2.9 & 1442 & $57 \%$ & 638 & 1442 & 1021 \\
\hline 2009 & 2.7 & 1717 & $57 \%$ & 546 & 1717 & 1022 \\
\hline 2010 & 2.8 & 1806 & $59 \%$ & 504 & 1806 & 1008 \\
\hline 2011 & 2.7 & 1714 & $56 \%$ & 528 & 1714 & 982 \\
\hline 2012 & 2.8 & 1708 & $59 \%$ & 490 & 1708 & 977 \\
\hline Aver & & & & & & \\
\hline
\end{tabular}


Table 13: Averages of estimated elasticity of VA to inputs

\begin{tabular}{lcccccc}
\hline \multirow{2}{*}{ Functional Form } & Proxy Vars. & $\beta_{l}$ & $\beta_{k}$ & $\beta_{l l}$ & $\beta_{k k}$ & $\beta_{l k}$ \\
& Material \& Services & .660 & .277 & & & \\
\hline Cobb-Douglas & & $(.147)$ & $(.149)$ & & & \\
& Material \& Services & .637 & .181 & .040 & .023 & -.056 \\
Trans-log & & $(.519)$ & $(.361)$ & $(.054)$ & $(.025)$ & $(.059)$ \\
& & & & & & \\
Trans-log & Material, Services \& $\Delta k_{i, t}$ & .664 & .149 & .044 & .026 & -.063 \\
& & $(.502)$ & $(.278)$ & $(.039)$ & $(.021)$ & $(.045)$
\end{tabular}

Figure 2 shows the trend in productivity over time. We plot the average (log) residual of value-added across firms (normalized at their 1998 level) estimated using 4 different techniques: the three whose average parameters are reported in Table 13 and the Solow residual calculated with $\beta_{\text {solow }}^{k}=.33$.

As the figure shows, that Italian manufacturing system did not improve its value added productivity over the last two decades. Large oscillations during the recent financial crisis may signal that residuals are strongly affected by demand conditions. Furthermore, it is interesting to notice that series deriving from estimated coefficients are much similar than the one obtained from Solow residuals. This may signal that simplistic estimate of productivity may be hampered by severe biases, pointing to the importance of using a more structural approach. 


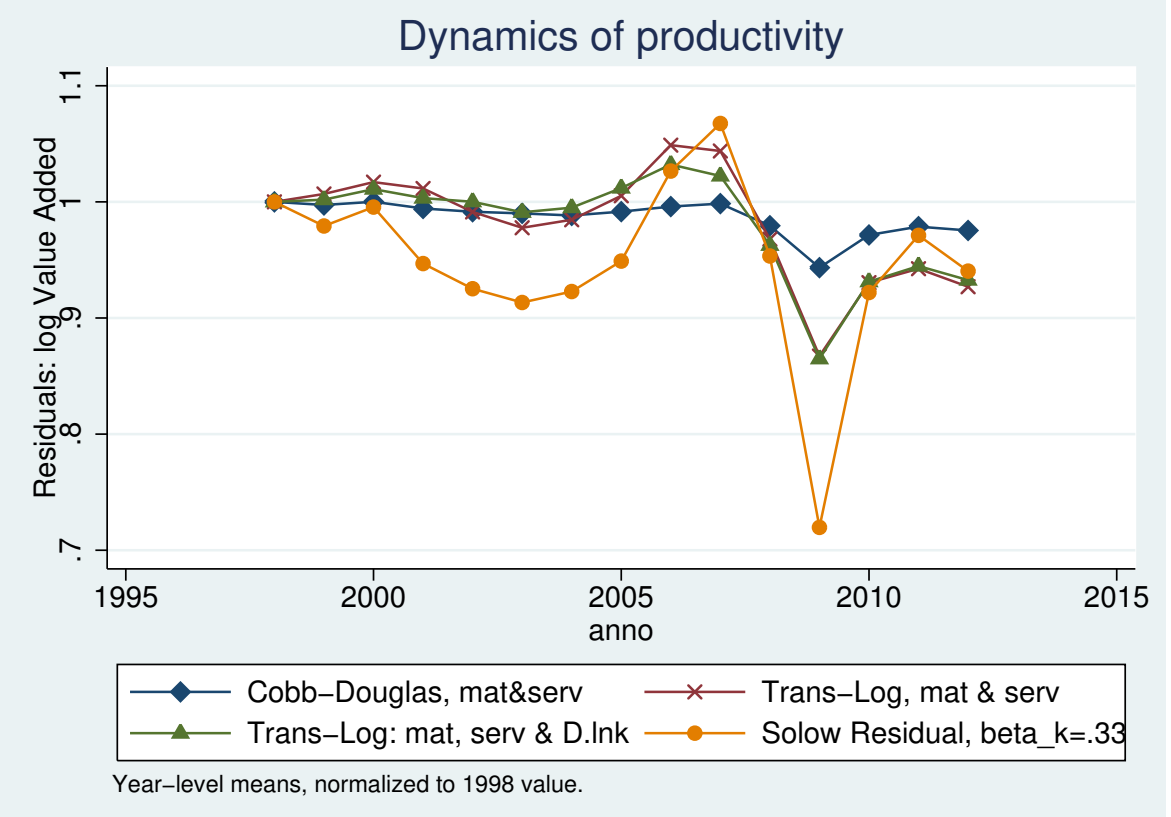

Figure 2: Average productivity - 1998-2008 
Table 14: Credit supply shifter on inputs

\begin{tabular}{|c|c|c|c|c|}
\hline VARIABLES & $\begin{array}{c}(1) \\
\Delta m a t_{i, t}\end{array}$ & $\begin{array}{c}(2) \\
\Delta s e r v_{i, t}\end{array}$ & $\begin{array}{c}(3) \\
\Delta k_{i, t}\end{array}$ & $\begin{array}{c}(4) \\
\Delta l_{i, t}\end{array}$ \\
\hline$s_{i, t}$ & $\begin{array}{l}0.0188 \\
(0.0260)\end{array}$ & $\begin{array}{r}-0.0319 \\
(0.0216)\end{array}$ & $\begin{array}{c}0.0902^{* * *} \\
(0.0196)\end{array}$ & $\begin{array}{c}0.00812 \\
(0.0157)\end{array}$ \\
\hline $\begin{array}{l}\text { Firm FEs } \\
\text { Year FEs }\end{array}$ & $\begin{array}{l}\mathrm{Y} \\
\mathrm{Y}\end{array}$ & $\begin{array}{l}\mathrm{Y} \\
\mathrm{Y}\end{array}$ & $\begin{array}{l}\mathrm{Y} \\
\mathrm{Y}\end{array}$ & $\begin{array}{l}\mathrm{Y} \\
\mathrm{Y}\end{array}$ \\
\hline $\begin{array}{l}\text { Observations } \\
R^{2}\end{array}$ & $\begin{array}{c}199043 \\
0.319\end{array}$ & $\begin{array}{c}222598 \\
0.269\end{array}$ & $\begin{array}{c}222629 \\
0.323\end{array}$ & $\begin{array}{c}222629 \\
0.318\end{array}$ \\
\hline mot ond & $\begin{array}{c}v_{i, t} \text { refer } \\
\text { Robust } \\
* * *\end{array}$ & $\begin{array}{l}\operatorname{logs} \text { of e } \\
\text { dard err } \\
01,{ }^{* *} \mathrm{p}\end{array}$ & $\begin{array}{l}\text { nditure for } \mathrm{n} \\
\text { in parenthese } \\
05,{ }^{*} \mathrm{p}<0.1\end{array}$ & and $\mathrm{s}$ \\
\hline
\end{tabular}




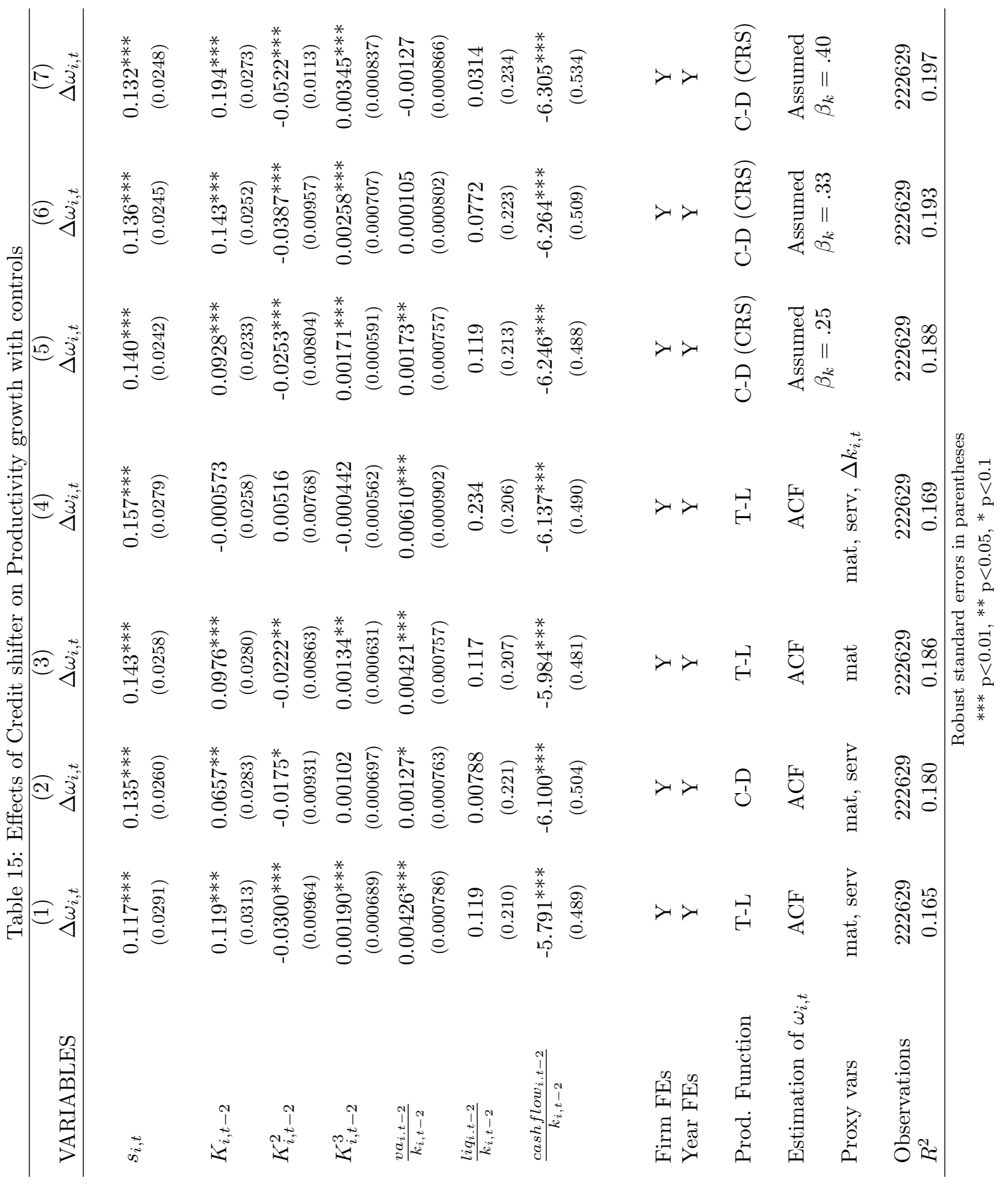


Table 16: Change in Credit Granted on Value Added and its input

\begin{tabular}{|c|c|c|c|c|c|c|}
\hline VARIABLES & $\begin{array}{c}(1) \\
\Delta k_{i, t}\end{array}$ & $\begin{array}{c}(2) \\
\Delta k_{i, t}\end{array}$ & $\begin{array}{c}(3) \\
\Delta l_{i, t}\end{array}$ & $\begin{array}{c}(4) \\
\Delta l_{i, t}\end{array}$ & $\begin{array}{c}(5) \\
\Delta v a_{i, t}\end{array}$ & $\begin{array}{c}(6) \\
\Delta v a_{i, t}\end{array}$ \\
\hline$\Delta c_{i, t}$ & $\begin{array}{c}0.0810^{* * *} \\
(0.00280)\end{array}$ & $\begin{array}{c}0.0744^{* * *} \\
(0.00271)\end{array}$ & $\begin{array}{c}0.0689 * * * \\
(0.00239)\end{array}$ & $\begin{array}{c}0.0678 * * * \\
(0.00238)\end{array}$ & $\begin{array}{c}0.0723^{* * *} \\
(0.00358)\end{array}$ & $\begin{array}{c}0.0717 * * * \\
(0.00357)\end{array}$ \\
\hline$K_{i, t-2}$ & & $\begin{array}{c}-1.019 * * * \\
(0.0651)\end{array}$ & & $\begin{array}{c}-0.327^{* * *} \\
(0.0273)\end{array}$ & & $\begin{array}{c}-0.416^{* * *} \\
(0.0355)\end{array}$ \\
\hline$K_{i, t-2}^{2}$ & & $\begin{array}{c}0.271^{* * *} \\
(0.0408)\end{array}$ & & $\begin{array}{c}0.0888 * * * \\
(0.0131)\end{array}$ & & $\begin{array}{c}0.111^{* * *} \\
(0.0160)\end{array}$ \\
\hline$K_{i, t-2}^{3}$ & & $\begin{array}{c}-0.0175^{* * *} \\
(0.00307)\end{array}$ & & $\begin{array}{c}-0.00581^{* * *} \\
(0.000988)\end{array}$ & & $\begin{array}{c}-0.00711^{* * *} \\
(0.00118)\end{array}$ \\
\hline$\frac{v a_{i . t-2}}{k_{i, t-2}}$ & & $\begin{array}{c}0.0183^{* * *} \\
(0.00211)\end{array}$ & & $\begin{array}{c}-0.00358^{* * *} \\
(0.000763)\end{array}$ & & $\begin{array}{c}0.00392^{* * *} \\
(0.000853)\end{array}$ \\
\hline$\frac{l i q_{i . t-2}}{k_{i, t-2}}$ & & $\begin{array}{c}1.009^{* * *} \\
(0.298)\end{array}$ & & $\begin{array}{c}0.513^{* * *} \\
(0.175)\end{array}$ & & $\begin{array}{c}0.741^{* * *} \\
(0.206)\end{array}$ \\
\hline$\frac{\text { cashflow }_{i . t-2}}{k_{i, t-2}}$ & & $\begin{array}{c}1.889^{* * * *} \\
(0.728)\end{array}$ & & $\begin{array}{c}1.675^{* * *} \\
(0.358)\end{array}$ & & $\begin{array}{c}-5.132^{* * *} \\
(0.488)\end{array}$ \\
\hline Firm FEs & $\mathrm{Y}$ & $\mathrm{Y}$ & Y & $\mathrm{Y}$ & Y & $\mathrm{Y}$ \\
\hline Year FEs & $\mathrm{Y}$ & $\mathrm{Y}$ & Y & $\mathrm{Y}$ & Y & $\mathrm{Y}$ \\
\hline $\begin{array}{l}\text { Observations } \\
R^{2}\end{array}$ & $\begin{array}{c}207823 \\
0.337\end{array}$ & $\begin{array}{c}207823 \\
0.378\end{array}$ & $\begin{array}{c}207823 \\
0.333\end{array}$ & $\begin{array}{c}207823 \\
0.336\end{array}$ & $\begin{array}{c}207823 \\
0.238\end{array}$ & $\begin{array}{c}207823 \\
0.240\end{array}$ \\
\hline
\end{tabular}


Table 17: Effects of Credit shifter on Productivity growth, 1\% threshold

\begin{tabular}{|c|c|c|c|c|c|c|c|}
\hline VARIABLES & $\begin{array}{c}(1) \\
\Delta \omega_{i, t}\end{array}$ & $\begin{array}{c}(2) \\
\Delta \omega_{i, t}\end{array}$ & $\begin{array}{c}(3) \\
\Delta \omega_{i, t}\end{array}$ & $\begin{array}{c}(4) \\
\Delta \omega_{i, t}\end{array}$ & $\begin{array}{c}(5) \\
\Delta \omega_{i, t}\end{array}$ & $\begin{array}{c}(6) \\
\Delta \omega_{i, t}\end{array}$ & $\begin{array}{c}(7) \\
\Delta \omega_{i, t}\end{array}$ \\
\hline$s_{i, t}$ & $\begin{array}{c}0.101^{* *} \\
(0.0442)\end{array}$ & $\begin{array}{c}0.144^{* * *} \\
(0.0290)\end{array}$ & $\begin{array}{c}0.156^{* * *} \\
(0.0288)\end{array}$ & $\begin{array}{c}0.119^{* * *} \\
(0.0388)\end{array}$ & $\begin{array}{c}0.149 * * * \\
(0.0271)\end{array}$ & $\begin{array}{c}0.143^{* * *} \\
(0.0275)\end{array}$ & $\begin{array}{c}0.137^{* * *} \\
(0.0279)\end{array}$ \\
\hline $\begin{array}{l}\text { Firm FEs } \\
\text { Year FEs }\end{array}$ & $\begin{array}{l}\mathrm{Y} \\
\mathrm{Y}\end{array}$ & $\begin{array}{l}\mathrm{Y} \\
\mathrm{Y}\end{array}$ & $\begin{array}{l}\mathrm{Y} \\
\mathrm{Y}\end{array}$ & $\begin{array}{l}\mathrm{Y} \\
\mathrm{Y}\end{array}$ & $\begin{array}{l}\mathrm{Y} \\
\mathrm{Y}\end{array}$ & $\begin{array}{l}\mathrm{Y} \\
\mathrm{Y}\end{array}$ & $\begin{array}{l}\mathrm{Y} \\
\mathrm{Y}\end{array}$ \\
\hline Prod. Function & T-L & C-D & T-L & T-L & C-D (CRS) & C-D (CRS) & C-D (CRS) \\
\hline Estimation of $\omega_{i, t}$ & $\mathrm{ACF}$ & $\mathrm{ACF}$ & $\mathrm{ACF}$ & $\mathrm{ACF}$ & $\begin{array}{c}\text { Assumed } \\
\beta_{k}=.25\end{array}$ & $\begin{array}{c}\text { Assumed } \\
\beta_{k}=.33\end{array}$ & $\begin{array}{c}\text { Assumed } \\
\beta_{k}=.40\end{array}$ \\
\hline Proxy vars & mat, serv & mat, serv & mat & mat, serv, $\Delta k_{i, t}$ & & & \\
\hline Observations & 179098 & 179098 & 179098 & 179098 & 179098 & 179098 & 179098 \\
\hline$R^{2}$ & 0.138 & 0.194 & 0.200 & 0.145 & 0.201 & 0.205 & 0.208 \\
\hline
\end{tabular}


Table 18: Credit supply shifter on Productivity, different FEs Structures

\begin{tabular}{lcccc}
\hline & $(1)$ & $(2)$ & $(3)$ & $(4)$ \\
VARIABLES & $\Delta \omega_{i, t}$ & $\Delta \omega_{i, t}$ & $\Delta \omega_{i, t}$ & $\Delta \omega_{i, t}$ \\
\hline \multirow{5}{*}{$s_{i, t}$} & & & & \\
& $0.0403^{* *}$ & $0.0637^{* * *}$ & $0.0976^{* * *}$ & $0.131^{* * *}$ \\
& $(0.0174)$ & $(0.0179)$ & $(0.0290)$ & $(0.0261)$
\end{tabular}

\begin{tabular}{|c|c|c|c|c|}
\hline Year FEs & Y & $\mathrm{Y}$ & $\mathrm{Y}$ & $\mathrm{Y}$ \\
\hline Firm FEs & & & $\mathrm{Y}$ & $\mathrm{Y}$ \\
\hline Province FEs & & $\mathrm{Y}$ & $\mathrm{Y}$ & \\
\hline $\begin{array}{l}\text { Year } \times \text { Province } \\
\times \text { Sector }\end{array}$ & & & $\mathrm{Y}$ & \\
\hline $\begin{array}{l}\text { Observations } \\
D^{2}\end{array}$ & 222629 & 222629 & 222629 & 222629 \\
\hline$R^{2}$ & 0.027 & 0.033 & 0.310 & 0.177 \\
\hline
\end{tabular}




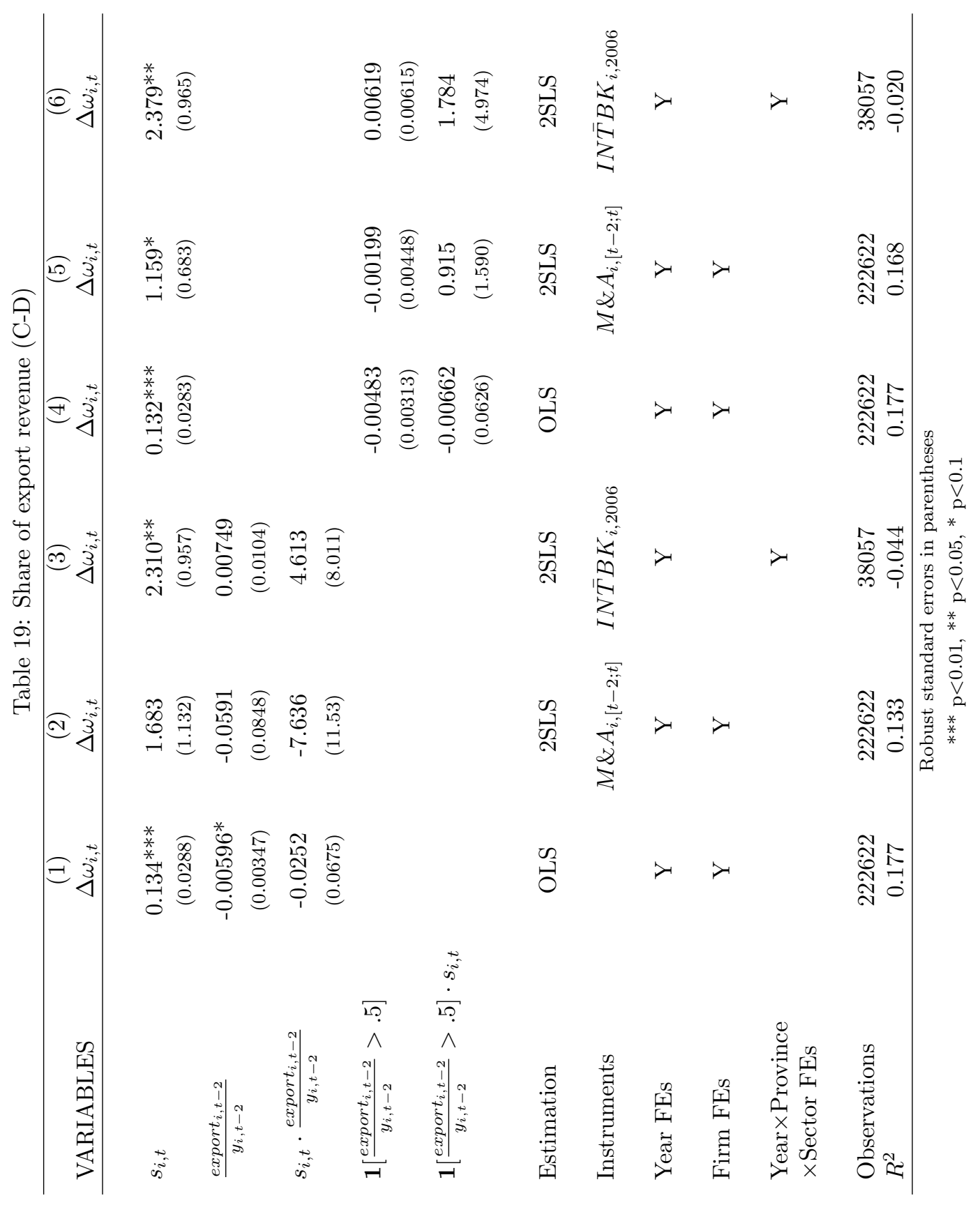




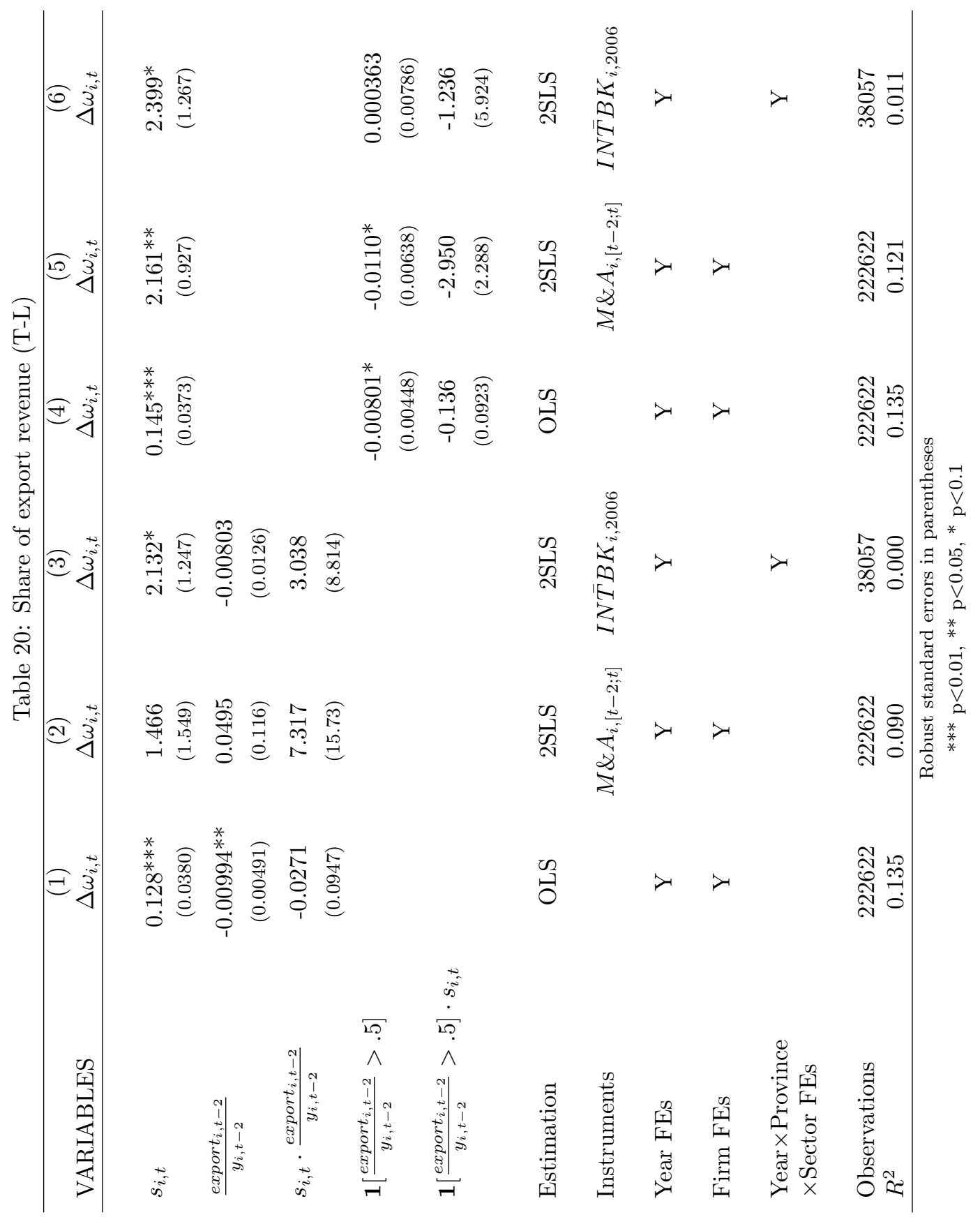


Table 21: Persistence (C-D)

\begin{tabular}{|c|c|c|c|c|}
\hline VARIABLES & $\begin{array}{c}(1) \\
\Delta \omega_{i, t}\end{array}$ & $\begin{array}{c}(2) \\
\Delta \omega_{i, t}\end{array}$ & $\begin{array}{l}(3) \\
\omega_{i, t} \\
\end{array}$ & $\begin{array}{l}(4) \\
\omega_{i, t}\end{array}$ \\
\hline$s_{i, t}$ & $\begin{array}{c}0.164^{* * *} \\
(0.0322)\end{array}$ & $\begin{array}{c}0.205^{* * *} \\
(0.0328)\end{array}$ & $\begin{array}{c}0.192^{* * *} \\
(0.0355)\end{array}$ & $\begin{array}{c}0.190^{* * *} \\
(0.0303)\end{array}$ \\
\hline$s_{i, t-1}$ & $\begin{array}{l}-0.0196 \\
(0.0334)\end{array}$ & $\begin{array}{c}0.0585^{*} \\
(0.0324)\end{array}$ & $\begin{array}{c}0.161^{* * *} \\
(0.0330)\end{array}$ & $\begin{array}{c}0.0830 * * * \\
(0.0297)\end{array}$ \\
\hline$s_{i, t-2}$ & $\begin{array}{c}-0.0929 * * * \\
(0.0349)\end{array}$ & $\begin{array}{c}-0.0721^{* *} \\
(0.0334)\end{array}$ & $\begin{array}{c}0.0693^{* *} \\
(0.0323)\end{array}$ & $\begin{array}{l}-0.0189 \\
(0.0300)\end{array}$ \\
\hline$s_{i, t-3}$ & $\begin{array}{l}0.0305 \\
(0.0320)\end{array}$ & $\begin{array}{c}-0.000333 \\
(0.0320)\end{array}$ & $\begin{array}{c}0.119^{* * *} \\
(0.0338)\end{array}$ & $\begin{array}{c}0.0653^{* *} \\
(0.0290)\end{array}$ \\
\hline$\Delta \omega_{i, t-1}$ & & $\begin{array}{c}-0.421^{* * *} \\
(0.00762)\end{array}$ & & \\
\hline$\Delta \omega_{i, t-2}$ & & $\begin{array}{c}-0.232^{* * *} \\
(0.00574)\end{array}$ & & \\
\hline$\Delta \omega_{i, t-3}$ & & $\begin{array}{c}-0.140^{* * *} \\
(0.00512)\end{array}$ & & \\
\hline$\omega_{i, t-1}$ & & & & $\begin{array}{c}0.421^{* * *} \\
(0.00781)\end{array}$ \\
\hline$\omega_{i, t-2}$ & & & & $\begin{array}{c}0.0710^{* * *} \\
(0.00654)\end{array}$ \\
\hline$\omega_{i, t-3}$ & & & & $\begin{array}{c}-0.00260 \\
(0.00511)\end{array}$ \\
\hline Year FEs & Y & Y & $\mathrm{Y}$ & $\mathrm{Y}$ \\
\hline Firm FEs & Y & Y & $\mathrm{Y}$ & $\mathrm{Y}$ \\
\hline Observations & 170367 & 151852 & 170367 & 166292 \\
\hline$R^{2}$ & 0.199 & 0.302 & 0.875 & 0.897 \\
\hline
\end{tabular}


Table 22: Persistence (T-L)

\begin{tabular}{|c|c|c|c|c|}
\hline VARIABLES & $\begin{array}{c}(1) \\
\Delta \omega_{i, t}\end{array}$ & $\begin{array}{c}(2) \\
\Delta \omega_{i, t}\end{array}$ & $\begin{array}{l}(3) \\
\omega_{i, t} \\
\end{array}$ & $\begin{array}{c}(4) \\
\omega_{i, t}\end{array}$ \\
\hline$s_{i, t}$ & $\begin{array}{c}0.154^{* * *} \\
(0.0431)\end{array}$ & $\begin{array}{c}0.228^{* * *} \\
(0.0456)\end{array}$ & $\begin{array}{c}0.312^{* * *} \\
(0.0524)\end{array}$ & $\begin{array}{c}0.231^{* * *} \\
(0.0416)\end{array}$ \\
\hline$s_{i, t-1}$ & $\begin{array}{c}-0.00163 \\
(0.0445)\end{array}$ & $\begin{array}{l}0.0602 \\
(0.0448)\end{array}$ & $\begin{array}{c}0.245^{* * *} \\
(0.0476)\end{array}$ & $\begin{array}{c}0.106^{* * *} \\
(0.0402)\end{array}$ \\
\hline$s_{i, t-2}$ & $\begin{array}{c}-0.0778^{*} \\
(0.0460)\end{array}$ & $\begin{array}{r}-0.0677 \\
(0.0456)\end{array}$ & $\begin{array}{c}0.0964^{* *} \\
(0.0470)\end{array}$ & $\begin{array}{c}-0.00312 \\
(0.0406)\end{array}$ \\
\hline$s_{i, t-3}$ & $\begin{array}{c}-0.00265 \\
(0.0422)\end{array}$ & $\begin{array}{r}-0.0227 \\
(0.0440)\end{array}$ & $\begin{array}{c}0.122^{* *} \\
(0.0493)\end{array}$ & $\begin{array}{l}0.0448 \\
(0.0391)\end{array}$ \\
\hline$\Delta \omega_{i, t-1}$ & & $\begin{array}{c}-0.343^{* * *} \\
(0.00858)\end{array}$ & & \\
\hline$\Delta \omega_{i, t-2}$ & & $\begin{array}{c}-0.203^{* * *} \\
(0.00714)\end{array}$ & & \\
\hline$\Delta \omega_{i, t-3}$ & & $\begin{array}{c}-0.130 * * * \\
(0.00665)\end{array}$ & & \\
\hline$\omega_{i, t-1}$ & & & & $\begin{array}{c}0.501^{* * *} \\
(0.00885)\end{array}$ \\
\hline$\omega_{i, t-2}$ & & & & $\begin{array}{c}0.0537 * * * \\
(0.00746)\end{array}$ \\
\hline$\omega_{i, t-3}$ & & & & $\begin{array}{c}-0.0205^{* * *} \\
(0.00676)\end{array}$ \\
\hline Year FEs & $\mathrm{Y}$ & $\mathrm{Y}$ & $\mathrm{Y}$ & $\mathrm{Y}$ \\
\hline Firm FEs & $\mathrm{Y}$ & Y & $\mathrm{Y}$ & $\mathrm{Y}$ \\
\hline Observations & 170367 & 151852 & 170367 & 166292 \\
\hline$R^{2}$ & 0.152 & 0.239 & 0.943 & 0.957 \\
\hline
\end{tabular}

